\title{
Price Effects of Horizontal Mergers
}

\author{
Alan A. Fisher, $\dagger$ \\ Frederick I. Johnson, $\dagger \dagger$ \\ and Robert H. Lande $\dagger_{\dagger} \dagger$
}

When should the government challenge a merger that might increase market power but also generate efficiency gains? The dominant belief has been that the government and courts should evaluate these mergers solely in terms of economic efficiency. Congress, however, wanted the courts to stop any merger significantly likely to raise prices. Substantially likely efficiency gains should therefore affect the legality of mergers to the extent that they are likely to prevent price increases. This standard is more strict than the economic efficiency criterion, because the latter would permit mergers substantially likely to lead to higher prices, if sufficient efficiency gains were substantially likely.

The authors analyze the competing price effects of market power increases and efficiency gains in the most relevant context: significant mergers in concentrated markets-oligopoly. They derive four general oligopoly models and evaluate them over all reasonable ranges for their underlying parameters. This methodology avoids biases due to overly restrictive assumptions.

By using the Merger Guideline standards and data from mergers that the Federal Trade Commission closely examined during 1982-86, the authors analyze empirically relevant tradeoffs between market power increases and efficiency gains. They find that decreases in marginal costs of 0 to $9 \%$ could be necessary to prevent price gains from mergers typical

$\dagger$ Bureau of Economics, Federal Trade Commission, Washington, D.C. Ph.D. 1973, University of California, Berkeley.

if Senior Economist, General Motors Corporation. Formerly Assistant Director for Antitrust, Bureau of Economics, Federal Trade Commission, Washington, D.C. Ph.D. 1980, University of Minnesota.

†t广 Assistant Professor, University of Baltimore School of Law. J.D. 1978, Harvard University; M.P.P. 1978, John F. Kennedy School of Government, Harvard University.

The opinions in this article are solely ours and do not necessarily express the views of our colleagues, the Bureau of Economics, the Commission, any individual Commissioner, or General Motors Corporation.

This article incorporates and extends the analysis in Mergers, Market Power, and Property Rights: When Will Efficiencies Prevent Price Increases?, Federal Trade Commission Working Paper No. 130 (Sept. 1985).

We thank Jonathan B. Baker, William Blumenthal, Alan J. Daskin, Kenneth G. Elzinga, William T. Fryer III, V. Rock Grundman, Barry C. Harris, Thomas M. Jorde, Thomas G. Krattenmaker, John E. Kwoka, Jr., David T. Levy, Victoria F. Nourse, Daniel L. Rubinfeld, Steven C. Salop, and Oliver E. Williamson for useful comments on earlier drafts. 
of those the government regularly evaluates. Cost savings in the upper portions of this range are far larger than those that previous authors have suggested would be necessary to compensate for efficiency losses from most mergers. They are also far greater than efficiency gains that one could realistically predict from virtually any merger. Moreover, if a merger significantly increased the probability of collusion, the required cost savings would be even greater.

The authors' models and a large number of practical considerations suggest that implicit consideration of efficiency gains, through adjustment of the standards for horizontal mergers, would be better than an explicit case-by-case efficiency defense.

\section{I}

\section{Balancing Market Power and Efficiency Gains}

When should the government challenge a merger that might increase market power but also generate efficiency gains? The antitrust community continues to struggle for the optimal way to handle such mergers, which can arise from large combinations in concentrated markets-oligopoly. Controversy over proper treatment of these difficult mergers contrasts with general agreement over policy making for the majority of mergers. The enforcement agencies and courts permit most mergers, because they are unlikely to lessen competition substantially. ${ }^{1}$ The enforcement system also typically blocks mergers that seem likely to decrease competition substantially and unlikely to generate otherwise unavailable efficiency gains. ${ }^{2}$ Large mergers in concentrated markets that promise significant efficiency gains, however, have long perplexed the antitrust enforcement system.

The enforcement system's ability to evaluate these difficult mergers depends on three related factors: decision-making criteria, evaluative techniques, and workability. The enforcement system's decision-making

1. The Clayton Act prohibits mergers whose effect "may be substantially to lessen competition, or to tend to create a monopoly." Clayton Act $\S 7,15$ U.S.C. $\S 18$ (1982). Somc representative statistics indicate how few mergers have this effect. Of the 868 filings made during 1979 under the Hart-Scott-Rodino Antitrust Improvements Act of 1976 [hereinafter Hart-ScottRodino Act], 15 U.S.C. $\$ 18 \mathrm{a}$ (1982), the relatively interventionist Carter administration requested additional information ("second requests") for only 109 (12.6\%) and challenged only 20 mergers (2.3\%). The Federal Trade Commission, led by activist Chairman Michael Pertschuk, issued 58 second requests, and the Department of Justice [hereinafter the Department] issued 51; each enforcement agency challenged 10 mergers. See P. Rodino, Rodino Announces Hearing on Antitrust Enforcement 3 (Mar. 2, 1988) (news release) (on file with the authors).

2. When evaluating a proposed merger, antitrust enforcement agencies should not consider as an offset potential efficiency gains that are speculative, unprovable, or attainable through less anticompetitive means. Economic efficiency occurs when there is no way to reallocate resources or goods to make any individual better off without making someone else worse off. Perfect competition in all markets ensures economic efficiency. See E. MANSFIELD, Microeconomics: THEORY AND APPLiCATIONS $438-49$ (4th ed. 1982). 
criteria must reflect the antimerger statutes' congressional mandate. The enforcement system must also use some coherent technique to balance the procompetitive (efficiency) and anticompetitive (market power) effects of mergers. And the system must be workable-that is, it must produce comprehensible and predictable decisions.

The Reagan administration's sole criterion for its merger policy was usually to maximize econounic efficiency. ${ }^{3}$ Under this criterion, market power is undesirable only because it increases allocative inefficiency; ${ }^{4}$ wealth transfers are irrelevant. A merger that improved economic efficiency would therefore be beneficial even if it led to higher consumer

3. Former Assistant Attorney General for Antitrust Charles F. Rule stated that "all too often" those who would include values other than efficiency in antitrust are engaging in "demagoguery." C. Rule, Antitrust, Consumers and Small Business 1 (Nov. 13, 1987) (remarks at the 2lst New England Antitrust Conference, Harvard Law School) (on file with the authors). Former Assistant Attorney General for Antitrust J. Paul McGrath stated that the primary goal of the Division during his and William F. Baxter's tenures was "to reinforce the notion that the sole basis of antitrust enforcement should be that decisions should be based on economic efficiency notions . . ." 60 Minutes with J. Paul McGrath, Assistant Attorney General, Antitrust Division, 54 ANTIrrust L.J. 129, 131 (1985) (statement of J. Paul McGrath) [hereinafter McGrath Statement]; see also [FTC Commissioner] Calvani, Consumer Welfare Is Prime Objective of Antitrust, Legal Times, Dec. 24/31, 1984, at 14, col. 1; Baxter, Responding to the Reaction: The Draftsman's View, 71 Calif. L. Rev. 618, 619-20 (1983) [hereinafter Draftsman's View]; Baxter, Separation of Powers, Prosecutorial Discretion, and the "Common Law" Nature of Antitrust Law, 60 TEx. L. REV. 661, 692-94 (1982).

However, the administration has in practice sometimes used or advocated a price standard. For example, Daniel Oliver, while Federal Trade Commission chairman, described the Commission's method of analyzing mergers: "[T] $]$ he crucial question is whether such transactions will substantially lessen competition-and hence injure consumers-by increasing price or reducing output." 60 Minutes with Daniel Oliver, Chairman, Federal Trade Commission, 57 ANTITRUsT L.J. 235, 237 (1988), (statement of Chairmau Oliver) [hereinafter Oliver]. For other examples, see infra notes 5051,110 .

4. To raise prices, firms with market power reduce output below the competitive level. The goods no longer sold would have been worth more to would-be purchasers than they would have cost society to produce. The difference between the maximum amount that consumers would have paid and the amount they actually pay is consumers' surplus. E. MANSFIELD, supra note 2, at 95. This foregone production of goods worth more than their cost constitutes lost consumers' surplus, a pure social loss that economists call a deadweight loss, or the allocative inefficiency from market power. For example, suppose that wickets cost $\$ 1$ in a competitive market and that we define cost to include a normal profit. Suppose that a firm with market power would sell them for \$1.25 each. A potential purchaser who would have been willing to pay up to $\$ 1.15$ would not pay $\$ 1.25$ for wickets. Since a competitive market would have enabled her to purchase wickets for less than they were worth to her, the reduced production in the market has decreased the consumer's satisfaction without producing any countervailing benefits for anyone. For an extended discussion and a formal proof that prices greater than the competitive price generate allocative inefficiency, see id. at 277-92; see also infra Figure 1 and text accompanying notes 40-43.

Higher prices transfer wealth from consumers to firms with market power. The difference between the actual price and the minimum amount that firms would require to keep them in production (full economic cost, including a normal rate of return on time and invested capital) is producers' surplus. Market power transforms consumers' surplus into producers' surplus. However, because of allocative inefficiency, the loss in consumers' surplus always exceeds the gain in producers' surplus. See E. MANSFIELD, supra note 2, at 290-92. 
prices and transferred wealth from consumers to firms with market power.

Even if one assumed that economic efficiency should be the sole criterion to judge mergers, one would still face the technical question of how large efficiency gains would need to be to compensate for market power increases, either in individual mergers or in general..$^{5}$ To our knowledge, the Reagan administration did not present its opinion, and the antitrust literature has widely different recommendations. ${ }^{6}$

Whatever the technical determination of the extent of efficiency gains necessary to offset increased market power, antitrust policy must be workable. The antitrust enforcers' decisions must be objective, coherent, and predictable. Ideally, the rules should be clear enough that business managers and government officials would know with a high degree of certainty which proposed mergers would be permitted and which would fail.

Virtually every current resolution of the market power/efficiency tradeoff follows in part from two basic assumptions: that economic efficiency should be the sole goal of antitrust enforcement, ${ }^{7}$ and that it is the only workable standard. ${ }^{8}$ We dispute both contentions.

We believe that Congress passed the antitrust statutes primarily to

5. Scholars typically use Williamson's formulation to phrase the question: By what percentage must costs decrease to compensate for expected allocative inefficiency from market power effects? See Williamson, Economies as an Antitrust Defense: The Welfare Tradeoffs, 58 AM. EcoN. REv. 18, 22-23, 34 (1968). Antitrust scholars have differed widely in the amount of efficiency gains that they consider necessary to compensate for most allocative inefficiency effects. For example, Muris would require an efficiency gain of one to two percent. Muris, The Efficiency Defense Under Section 7 of the Clayton Act, 30 CASE W. RES. L. REv. 381, 420 (1980). Areeda and Turner would require an increase of five percent. P. AREedA \& D. TURNer, 4 ANTITRust LAw I 946e (1980). The specific tradeoff values are highly sensitive to details of the modeling, even under the simplest assumptions. Fisher \& Lande, Efficiency Considerations in Merger Enforcement, 71 CALIF. L. REv. $1580,1630-44,1668-69$ (1983).

6. See supra note 5; see also Edwards, Joffe, Kolasky, McGowan, Mendez-Penate, Ordover, Proger, Solomon \& Toepke, Proposed Revisions of the Justice Department's Merger Guidelines, 81 COLUM. L. REV. 1543 (1981).

7. Those who believe that economic efficiency was the sole concern of the authors of the antitrust statutes typically rely on Judge Robert Bork's analysis of the legislative history of these statutes. Judge Bork argues that the sole goal of antitrust enforcement should be to ensure that productive efficiency mitigates any allocative inefficiency from enhanced market power and resulting higher prices. Bork, Legislative Intent and the Policy of the Sherman Act, 9 J.L. \& EcoN. 7 (1966); see also R. Bork, The ANTITRUST PARAdox 50-71, 91 (1978). We disagree with Judge Bork.

8. The sole exception is the Guidelines of the National Assoeiation of Attorneys General, which follow our suggested approach: "When a firm or firms exercise market power by profitably maintaining prices above competitive levels for a significant period of time, a transfer of wealth from consumers to those firms oceurs. This transfer of wealth is the major evil sought to be addressed by section 7." National Association of Attorneys General, Horizontal Merger Guidelines of the National Association of Attorneys General [hereinafter NAAG Guidelines], reprinted in 52 Antitrust \& Trade Reg. Rep. (BNA) No. 1306, Special Supp. at S-4 (Mar. 12, 1987) (footnotes omitted). 
prevent firms from acquiring the ability to raise prices and thereby extract wealth from consumers. ${ }^{9}$ Congress wanted to block any merger significantly likely to generate higher consumer prices; it did not focus directly on efficiency consequences. ${ }^{10}$ This price standard is virtually equivalent to one that proscribes anticompetitive restrictions in output. ${ }^{11}$

Advocates of economic efficiency as the sole criterion of antitrust enforcement might challenge our wealth transfer (price) approach as unworkable. For example, former Assistant Attorney General Baxter compared an economic efficiency standard to "social and political stan'dards. . . . stated in vague, subjective ternns"12 and concluded that "economic efficiency provides the only workable standard from which to derive operational rules and by which the effectiveness of such rules can be judged."13 But this comparison ignores the price standard. Had Baxter compared the efficiency standard to a price standard, he should have reached a different conclusion. Our modeling demonstrates that in the relevant context for mergers-oligopoly-it is actually far easier to solve the market power/efficiency tradeoff for a price than an economic efficiency standard. ${ }^{14}$

Current antitrust enforcement also raises a difficult technical problem. Mergers likely to increase both market power and productive efficiency have an uncertain effect on price. Increased market power by

9. See infra notes 31-37 and accompanying text.

10. Congress did not oppose efficiency, but it was more concerned with preventing higher prices. For example, suppose that a proposed merger would probably increase market power and generate merger-specific cost savings, but the net effect would be to increase prices. The merger, if allowed, would enrich the merging firms but make consumers worse off. Our analysis suggests that the legislators who voted for the Celler-Kefauver Amendment, Pub. L. No. 81-899, 64 Stat. 1125 (1950) (codified as amended at 15 U.S.C. §§ 18, 21 (1982 and Supp. V 1987)), and the Clayton Act, Pub. L. No. 63-212, 38 Stat. 730 (1914), (codified as amended at 29 U.S.C. $\$ \S 52,53$ and scattered sections of 15 U.S.C. and 18 U.S.C. (1982 and Supp. V 1987)), would have wanted to stop such a merger.

11. The output and price standards are identical except when demand is completely unresponsive to small changes in price or when firms are able to practice certain forms of price discrimination.

This interpretation harmonizes the antimerger statutes with the Sherman Act's prohibition against anticompetitive "restraint[s] of trade." 15 U.S.C. \$1 (1982). A practice that "restrains" trade is essentially one that restrains (reduces) output.

12. Baxter, Draftsman's View, supra note 3 at 621 . "[C]ourts are not, I believe, entitled to balance such things as consumer welfare against small business welfare without engaging in a task that is so unconfinedly legislative as to be unconstitutional." Bork, The Role of the Courts in Applying Economics, 54 ANTITRUST L.J. 21, 24 (1985). The debates over workability have ignored the price standard. Bork, Baxter, et al. have instead convincingly demonstrated that an antitrust standard based on "big is bad, small is good" or other similar platitudes is unworkable. See $\mathbf{R}$. BORK, supra note 7.

13. Baxter, Drafisman's View, supra note 3, at 621; see also Calvani, supra note 3.

14. See infra notes 107-126 and accompanying text (section V.A). However, Judges Posner and Easterbrook, generally associated with the efficiency school, recommend an output standard (essentially a price standard) for workability reasons. See infra note 109 and accompanying text. 
itself tends to raise prices. ${ }^{15}$ But all firms base their prices in part on their costs, so improved productive efficiency tends to lower prices. ${ }^{16}$ How extensive must these efficiency gains be to offset the price effects of increased market power in a concentrated market?

In this article, we provide the first response both grounded in economic theory and based on the most relevant market context. We focus on price, not economic efficiency, as the appropriate criterion-or legal standard-by which the government and courts should evaluate proposed mergers. We focus on oligopoly, because we assume that there would be no merger enforcement in unconcentrated markets and that the antitrust agencies and courts would be unlikely to permit mergers expected to lead to monopoly or to an effective cartel. ${ }^{17}$ The enforcement agencies typically focus their policy analysis on intermediate situations similar to those that we evaluate.

The market power/efficiency tradeoff usually occurs in large mergers in concentrated markets that would result in neither a complete monopoly nor perfect collusion-in other words, oligopoly. Existing analyses, however, either assume an initial increase in price without explaining why mergers are likely to generate such large price increases or assume transformation of an initially competitive market to a monopolistic or perfectly collusive one. ${ }^{18}$ Moreover, because they do not consider data from the proposed mergers that enforcers and the courts actually evaluate, their conclusions may not be reliable.

To simulate the tradeoff without limiting the analysis by misleading assumptions, we use "theoretically neutral" assumptions to model the simultaneous effects of market power and efficiency in oligopoly. We use the latest standards of the Merger Guidelines and recent data on actual proposed mergers to define the critical parameters of our models. Our realistic model building and use of relevant data enable us to identify the

15. See E. MANSF1ELd, supra note 2, at 277-92; see generally J. BAIN, INDUSTRIAL Organization 113-24 (2d ed. 1968) (in a competitive market, no one firm can affect price; in oligopoly, each seller supplies a large enough share of industry output to affect price).

16. See infra notes 54-59 and accompanying text.

17. An efficiency standard, however, might permit some mergers likely to result in higher, even monopolistic, prices. For an analysis of the price effects of merger leading to monopoly, see Fisher, Lande \& Vandaele, Afterword: Could a Merger Lead to Both a Monopoly and a Lower Price?, 71 CAL.JF. L. REv. 1697 (1983).

The Commission explicitly considered whether to accept a negotiated consent in a merger that both the Bureau of Competition and the Bureau of Economics agreed would probably improve net economic efficiency but could result in higher, or perhaps even monopolistic, prices. The Commission voted three to one to accept the consent; Chairman Miller cast the only opposing vote, because he considered monopoly overcharges "revenue transfers" that should not factor into the enforcement analysis. In re Allied Corp., FTC File No. 811-0191 (Dec. 8, 1982), discussed in CostBenefit Analysis, Miller Style, FTC: Watch (Wash. Reg. Rep. Assoc.) No. 158, at 1 (Jan. 14, 1983). 50 .

18. For a critical discussion of the existing studies, see Fisher \& Lande, supra note 5, at 1624- 
extent of efficiency gains necessary to justify mergers that firms routinely propose. $^{19}$

But should courts and antitrust enforcers perform the market power/efficiency tradeoff on a case-by-case basis or on average, through merger guidelines? Merger guidelines implement the market power/efficiency balancing through structural "safe harbors" and presumptions of varying strengths that allow most merger-specific efficiency gains and prevent most adverse market power effects. While a guideline approach has almost universal approval, there is wide disagreement over treatment of mergers with significantly likely market power and efficiency effects. The most individualistic approach would be to perform a case-by-case tradeoff between increases in market power and gains in efficiency. The opposite extreme would be to incorporate the tradeoff implicitly by raising the structural threshold for illegality instead of allowing a case-bycase efficiency defense. The greater one's confidence in the abilities of business executives, government officials, and courts to perform the balancing accurately (and reach consistent conclusions) in individual merger cases, the stronger the argument for case-by-case evaluation. ${ }^{20}$

Antitrust enforcers during the Reagan administration tried various approaches to handle the market power/efficiency tradeoff. In the 1982 Merger Guidelines, the Department of Justice essentially followed the recommendations of Judges Bork, Posner, and Easterbrook and rejected a case-by-case efficiency defense "[e]xcept in extraordinary cases." 21 The Federal Trade Commission, in its Statement on Horizontal Mergers, adopted a similar approach. ${ }^{22}$ The administration soon changed its policy. The Department's 1984 Merger Guidelines proposed considering virtually all kinds of efficiency gains without explaining how it would do

19. All predictions of either market power or efficiency gains are probabilities, not certainties, and one should discount the calculations appropriately.

20. For an extensive discussion and the argument that the case-by-case approach is unmanageable in practice, see Fisher \& Lande, supra note 5, at 1670-77.

21. U.S. Dep't of Justice, Merger Guidelines § V.A, 47 Fed. Reg. 28,493, 28,501 (1982), reprinted in 2 Trade Reg. Rep. (CCH) \ 4501, ๆ 4505 (Aug. 9, 1982) [hereinafter 1982 Merger Guidelines]. For the recommendations of Judges Bork, Posner, and Easterbrook, see e.g., R. Posner \& F. EAsterbrook, ANtitrust: Cases, Economic Notes, and Other Materials 463-64, 920-21 (2d ed. 1981) ("But is an efficiencies defense manageable? For the reasons discussed in the previous note, the defense could bog down litigation for years. ... The effort seems unlikely to be worth the candle." Id. at 920-21); see also R. BORK, supra note 7, at 125-27; R. POSNER, ANTitrust LAw: AN Economic Perspective 112-13 (1976).

22. Federal Trade Commission, Statement on Horizontal Mergers, June 14, 1982, 凤 4516, at 6901-5, reprinted in 2 Trade Reg. Rep. (CCH) 4516, at 690I-5 (Sept. 10. 1984) [hereinafter FTC Statement]. For a demonstration that the practical effects of the 1982 Merger Guidelines and the FTC Statement should have been very similar, if followed, see Fisher \& Lande, supra note 5, at 1661 n.279, 1666-67. Chairman Miller disagreed with the Commission's statement, however, and would have considered scale-type efficiency gains in the legal analysis of individual cases. See FTC Statement, supra, at 6901-5 n.22. The Chairman's views soon became the majority position at the Commission. See infra note 24 and accompanying text. 
so, ${ }^{23}$ and the Commission argued at length that it was appropriate to consider anticipated efficiency gains in individual cases. ${ }^{24}$ The Reagan

23. U.S. Dep't of Justice, Justice Department Merger Guidelines, 49 Fed. Reg. 26,823 (1984), reprinted in 2 Trade Reg. Rep. (CCH) No. 655 If 4490-4495 (June 18, 1984) [hereinafter 1984 Merger Guidelines]. We use "Merger Guidelines" when a statement applies equally to the 1984 Merger Guidelines, id., and the 1982 Merger Guidelines, supra note 21. The Justice Department would like to limit consideration of efficiency gains to the discretion of prosecutors. See 1984 Merger Guidelines, supra, at $\$ 3.5$; c.f. Conference Board Seminar's Faculty Takes Cautious Approach to Enforcement Outlook, 56 Antitrust \& Trade Reg. Rep. (BNA) No. 1406, at 355 (Mar. 9, 1989) [hereinafter Conference Board Seminar] (remarks of Judge Easterbrook, commenting on the Reagan administration's internal evaluation practices). This policy, however, may not be viable in the long run. If the enforcers did not accept an acquiring firm's efficiency claims, the company would probably bring its efficiency claims before a court and argue that the court was equally or better qualified to evaluate them. Some courts would probably agree.

If the Justice Department and Commission follow the evidentiary standards in the $1984 \mathrm{Merger}$ Guidelines and the FTC Statement, an efficiency defense should virtually never succeed; compare the 1984 Merger Guidelines, id., with the language quoted and discussed in Fisher \& Lande, supra note 5 , at $1665 \mathrm{n} .279,1666-67$. Interpretation of the language, however, may vary between the agencies and over time. See infra notes 24, 79.

Professor Jorde concluded that this change in the 1984 Merger Guidelines constitutes "double counting" of efficiency gains. The 1982 Merger Guidelines broadened the definition of "relevant market" and raised the permissible level of market concentration to account for most efficiency gains. By keeping this higher threshold and adding consideration of efficiency gains in individual cases, the Department has given efficiency too much weight, according to Jorde. See Jorde, Coping With the Merger Guidelines and the Government's "Fix-It First" Approach: A Modest Appeal for More Information, 32 ANTITRUST BULL. 579, 591 (1987).

Judge Stephen G. Breyer recently commented that the merger guidelines have moved enforcement toward a "kitchen sink" standard where "everything is relevant" and away from the "bright line" process. Noted practitioner Ira $M$. Millstein complained that the Reagan administration used a secret, "unpublished" set of merger guidelines under which the Antitrust Division did not explain its decisions to permit many above-Guideline mergers, other than the ambiguous "prosecutorial discretion." Judge Breyer and Mr. Millstein made their remarks at the Conference Board's 28th annual Antitrust Issues in Today's Economy seminar on March 2, 1989. For a report on the conference that includes a discussion of Breyer's and Millstein's remarks, see Conference Board Seminar, supra, at 355.

24. In re American Medical Int'1, Inc., 104 F.T.C. 1, 213-20 (1984). In this opinion, where the Commission first directly addressed the proper treatment of the market power/efficiency tradeoff, the Commission ignored its own Merger Statement, see supra note 22, and examined the specific tradeoff between increased market power and efficiency gains. Since the Commission found no likely efficiency gain for the merger in question, American Medical International's extensive discussion in dicta of the legitimacy of a case-by-case efficiency defense seems to be an attempt to change policy. Internal merger analyses at both the Commission and Department now routinely evaluate efficiency claims.

Former Assistant Attorney General for Antitrust (now Judge) Douglas H. Ginsburg concluded from personal observation that an efficiency defense would rarely be successful:

Under the Merger Modernization Act [of 1986], an efficiency-enhancing but priceincreasing merger could be interdicted. As a matter of enforcement discretion, however, I would have been unlikely, as Assistant Attorney General, to have opposed a merger that was demonstrably efficient. At the same time, I hasten to point out, however, that I did not find the efficiencies claim persuasive in any of the admittedly few merger reviews where the point was argued....

... Particularly in view of the infrequency with which efficiency showings can convincingly be made on behalf of a proposed merger, a price-driven standard for mergers would do more to avoid lost efficiencies through over-enforcement (of the Von's Brown, or $P N B$ sort) than could possibly be lost by the occasional blocking of a merger that would be both price and efficiency enhancing. 
administration even tried to codify the case-by-case efficiency defense by amending Section 7 of the Clayton Act. ${ }^{25}$ The National Association of Attorneys General has suggested a middle ground: consider efficiency gains only for mergers of modest size in moderately concentrated markets but not for mergers in markets more concentrated than the highest structural benchmarks in the Merger Guidelines. ${ }^{26}$

Resolving this question requires an understanding of how difficult it is to balance changes in market power and efficiency. Even under a price standard, the increase in efficiency needed to balance market power and thus justify an above-Guideline merger is quite sensitive to the underlying assumptions. When one broadens the analysis to include qualitative efficiency gains, the analysis becomes vastly more difficult. The complexities of an accurate case-by-case efficiency defense lead us to conclude that whether one adopts a price or an efficiency standard, an individual case approach is too complex for the courts and antitrust enforcers. The best way to incorporate efficiency is therefore through merger guidelines that incorporate efficiency through threshold values, rather than guidelines that permit a case-by-case efficiency defense.

\section{II}

\section{The Intent of Congress: Price Versus Economic Efficiency}

Most leading scholars who have analyzed the legislative history of the antimerger laws have concluded that the primary concern of Congress was that mergers might enable businesses to restrict output and

Letter from Judge Douglas H. Ginsburg to Robert H. Lande (Feb. 3, 1988); but see infra note 69 (the staff attorneys or economists at the Federal Trade Commission advised the Commission in 19 of 70 above-Guideline mergers during June, 1982 to December, 1986 that they believed that the merger in question would be likely to generate significant efficiency gains).

25. The Reagan Administration tried several times to amend the Clayton Act. For the 1984 efforts, see Commerce Department is Examining Ways to Permit Mergers Yielding Efficiencies, 47 Antitrust \& Trade Reg. Rep. (BNA) No. 1185, at 655 (Oct. 11, 1984). For the 1986 efforts, see infra note 110 and accompanying text. For the substantially identical 1987 efforts, see Antitrust, Intellectual Property Reform Are Features of Competitiveness Package, 52 Antitrust \& Trade Reg. Rep. (BNA) No. 1303, at 328:1 (Feb. 19, 1987). A logical impetus behind the proposals to amend the merger standards could have been that Supreme Court and appellate court decisions, although somewhat old, seemed to disfavor the efficiency defense to anticipated increases in market power. Compare Fisher \& Lande, supra note 5, at 1593-99 (The Supreme Court held in 1967 that an efficiency defense was not available under section 7 of the Clayton Act; however, the availability of the defense under section 5 of the Federal Trade Commission Act remains an open question. Further, courts today might rule differently given the increased recognition of the importance of efficiency gains from mergers.) with In re American Medical Int'l Inc., 104 F.T.C. 1, 215-19 (1984) (arguing that the Supreme Court has stated in dicta a bias against an efficiency defense in merger cases, but that the Court has sometimes been willing to consider evidence of efficiency gains favorably in other antitrust contexts). See also infra note 130.

26. NAAG Guidelines, supra note 8, at S-9. 
raise prices. ${ }^{27}$ The dispute centers on which effect of higher prices Congress believed caused harm. ${ }^{28}$ Some scholars identify allocative inefficiency as the component of concern to Congress; ${ }^{29}$ we, however, agree with other analyses that point to wealth transfers as the primary issue. ${ }^{30}$

27. As Bork stated so eloquently, "The touchstone of illegality is raising prices to consumers. There were no exceptions." Bork, supra note 7, at 16. Bork also stated that the "rule against monopolistic mergers . . . [was] derived in large measure from a desire to protect consumers from monopoly extortion. . . . Where producer and consumer welfare might come into conflict, . . . Congress chose consumer welfare as decisive." Id. at 11. While Bork wrote in the context of the Sherman Act's legislative history, his summary aptly describes the congressional intent in passing the antimerger laws as well; see also R. POSNER, supra note 21, at 23 ("The framers of the Sherman Act appear to have been concerned mainly with the price and output consequences of monopolies

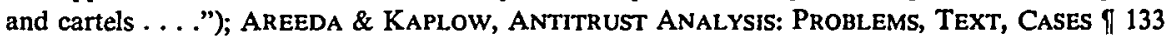
(4th ed. 1988) (using an output test as a "first and generally decisive test," except when the market power transfers wealth from consumers to producers). For additional examples, see sources that we cite infra at note 30. For further discussion, see Lande, Wealth Transfers as the Original and Primary Concern of Antitrust: The Efficiency Interpretation Challenged, 34 HASTiNGs L.J. 65, 12642 (1982).

There are a few exceptions, who focus on socio-political values. See, e.g., Bok, Section 7 of the Clayton Act and the Merging of Law and Economics, 74 HARV. L. REv. 226, 233-238 (1960) (Congress' main concern was a wide range of sociological problems associated with mergers and big business); see also Lande, supra, at $69 \mathrm{nn} .11-16$, for additional citations.

28. Congress simply wanted to prevent price rises resulting from mergers; ascertaining which of the effects of higher prices concerned Congress most is less important. However, to determine when a merger is likely to lead to higher prices, we must disaggregate efficiency and wealth-transfer effects.

29. See, e.g., R. BORK, supra note 7, at 91; R. POSNER, supra note 21, at 8-22. Bork's position seems inconsistent. See supra note 27. It is hard to believe that "monopoly extortion" means nothing more than allocative inefficiency.

Judge Easterbrook has long advocated an efficiency standard for the antitrust laws. See, e.g., Easterbrook, The Limits of Antitrust, 63 TExAS L. REv. 1, 3-4 (1984). His position might be starting to evolve. He recently concluded that when Congress enacted the Sherman Act, "The choice they saw was between leaving consumers at the mercy of trusts and authorizing the judges to protect consumers. However you slice the legislative history, the dominant theme is the protection of consumers from overcharges." Easterbrook, Workable Antitrust Policy, 84 Mich. L. REV. 1696, 1702-03 (1986). Easterbrook then asserted: "This turns out to be the same program as onc based on 'efficiency.' There are differences at the margins . . . but the differences are not very important ... [especially because] [i]n the long run consumers gain most from a policy that cmphasizes allocative and productive efficiency." Id. at 1703. Easterbrook thus appears to concede that the primary purpose of the antitrust laws is to prevent consumers from paying higher prices, but he seems to argue that the price standard is virtually the same as an efficiency standard.

30. See, e.g., Kaplow, The Accuracy of Traditional Market Power Analysis and a Direct Adjustment Alternative, 95 HARv. L. REv. 1817, 1822-23 (1982) (Congress was concerned with wealth transfers from consumers to dominant firms); Scherer, The Posnerian Harvest: Separating Wheat from Chaff (Book Review), 86 YALE L.J. 974, 979 (1977) (reviewing R. PoSNER, supra note 21 , and arguing that Congress was concerned at least as much with distributional effects as with efficiency); Fox, The Modernization of Antitrust: $A$ New Equilibrium, 66 CoRNELL L. REV. 1140, 1146-55 (1981) (one purpose of the antitrust laws was to stop wealth transfers from consumers and small suppliers to trusts); Hovenkamp, Antitrust Policy After Chicago, 84 Mich. L. REv. 213, 250-53 (1985) (Congress was "really concerned with protecting consumers from unfavorable wealth transfers." Id. at 250.); Harris \& Sullivan, Horizontal Merger Policy: Promoting Competition and American Competitiveness, 31 ANTITRUST BuLL. 871, 897 (1984) ("protecting consumers from exploitation and loss of income to producers" were Congress' objectives); Wiley, Antitrust and Core Theory, 54 U. CHI. L. REv. 556, 587-88 (1987) (Congress cared more about distributive justice than 
The legislators' principal concern was whether mergers would enable firms to raise prices and thereby unfairly transfer wealth from consumers (purchasers) to producers (sellers). ${ }^{31}$ Most supporters of the Celler-Kefauver Amendment considered the main economic issue to be the possibility of firuns with market power victimizing consumers. ${ }^{32}$ The opponents saw no substantial risk of such "unfairness," even without legislation. ${ }^{33}$ Some legislators expressed concern about the possible effects of the legislation on the productive efficiency of firms, but none of them explicitly recognized any tradeoff between losses to consumers through

economic efficiency); Kovacic, Public Choice and the Public Interest: Federal Trade Commission Antitrust Enforcement During the Reagan Administration, 33 ANTITRUST BULL. 467, 477-78 n.18 (1988) ("distributional concerns, not allocative efficiency, led Congress to pass [the antitrust statutes]"); see also AREEDA \& KAPLOW, supra note 27.

More generally, Nobel Laureate George Stigler argues that policy makers concentrate on wealth transfers and not on efficiency. See Stigler, Economists and Public Policy, 6 REg. May-June 1982 , at 13.

31. The most logical explanation of congressional intent is that in passing the antitrust laws Congress defined certain property rights or entitlements for the first time. In effect, Congress attempted to guarantee consumers the right to purchase competitively priced goods by declaring that consumers' surplus was the property of consumers. Congress condemned any mergers substantially likely to lead to supracompetitive pricing that would "unfairly" transfer this property to firms with market power. For an explanation of the concepts of consumers' and producers' surplus, see supra note 4. Its concern was not the distribution of wealth between the rich and the poor; Congress dealt here only with the more limited issue of the fair distribution of consumers' surplus between sellers and buyers. See Fisher \& Lande, supra note 5, at 1588-93. The most faithful way to implement this concern is to prevent mergers substantially likely to lead to higher prices or reduced output.

32. For example, Rep. Bennett wanted legislation to protect "the consuming public from unfair exploitation." 95 CoNG. REC. 11,506 (1949). Rep. Carroll accused certain companies of "maintaining high prices which injure the consumer," id. at 11,492, and called monopoly prices "outrageous prices," id.; see also id. at 11,492-94. Rep. Byrne quoted (with apparent approval) from an FTC report that stated: " [U]nder competitive capitalism consumers are protected from high prices by the constant rivalry among numerous firms for a greater share of the market.' "Id. at 11,506 (quoting Federal Trade Commission, The Merger Movement: A Summary Report 68 (1948)). Rep. Patman complained: "You know what a monopoly always does. It will do what is in the best interest of the people who own the monopoly." Id. at 7989. Sen. Kilgore wanted to protect "consumers" and "buyers" against "unjust exploitation." Corporate Mergers and Acquisitions: Hearings on H.R. 2734 Before a Subcomm. of the Senate Comm. on the Judiciary, 81st Cong., 1st \& 2d Sess. 180 (1950) [hereinafter cited as Senate Hearings]; see also 95 Cong. REc. 11,493 (1949) (statement of Rep. Yates).

Similar statements permeate the Clayton Act's legislative history. Rep. Hamlin expressed his distaste for monopoly pricing in these terms:

The only reason why trusts and combinations are declared illegal is because they are organized and operated for the express purpose of ... more effectively exploiting the people by taking advantage of their necessities and controlling the price of these necessities to the consumers, as well as the purchase price which they have to pay for the raw material.

51 CoNG Rec. 9556 (1914); see also id. at 9265 (statement of Rep. Morgan); id. at 14,223 (statement of Rep. Thompson).

33. Rep. Jennings, for example, stated that the merger amendment was unnecessary: "I do not subscribe to the doctrine that the businessmen of our country are crooks and that those who carry on their business through the instrumentality of corporations are out to fieece and extort higher and higher prices from their customers." 95 CoNG. REc. 11,490-91 (1949); see also Senate Hearings, supra note 32, at 308 (testimony of James L. Donnelly); id. at 251 (testimony of Benjamin C. Marsh). 
wealth transfers and gains to society through efficiency. Proponents of the antimerger statutes argued that monopolies would not increase productive efficiency, ${ }^{34}$ and opponents felt that mergers would improve efficiency but not increase market power. ${ }^{35}$

Moreover, Congress was surely unaware of even an intuitive version of the concept of allocative inefficiency in 1914 when it approved the Clayton Act; ${ }^{36}$ the notion that this concept could have caused Congress to pass the antimerger laws is hardly credible. ${ }^{37}$ Although economists had dramatically increased their understanding of allocative efficiency by 1950 when Congress enacted the Celler-Kafauver Amendment, ${ }^{38}$ the legislative history of this bill contains absolutely no mention of this concept. $^{39}$

Figure 1 contrasts the effects of the efficiency and price standards for

34. For example, Rep. Celler stated: "Bigness does not mean efficiency, a better product, or lower prices." 95 CONG. REC. 11,486 (1949); see also 95 CoNG. REC. 11,495-98 (1949) (statement of Rep. Boggs) (quoting Judge Learned Hand); Senate Hearings, supra note 32, at 308; Amending Sections 7 and 11 of the Clayton Act: Hearings on H.R. 988, H.R. 1240, H.R. 2006, and H.R. 2734 Before Subcomm. No. 3 of the House Comm. on the Judiciary, 81 st Cong., 1st Sess. 83-84 (1949) (statement of John M. Blair, Assistant Chief Economist, FTC) [hereinafter House Hearings].

Economists today would interpret a change in "productive efficiency" as a change in costs. See Fisher \& Lande, supra note 5, at 1599-604. The majority in Congress felt that mergers would reduce competition and lead to inefficient, lazy monopolists-what economists would now call $x$ inefficiency. The majority view, then, was that increased competition (disallowing mergers that might threaten competition) would mean lower, not higher, costs! Id. at 1599-604.

35. For example, Rep. Goodwin stated:

By preventing harmless and reasonable mergers among small and medium-sized concerns,

this bill ... will foreclose the chance that they may by consolidation or acquisition ever

approximate either the size or the efficiency that the big competitors have already achieved.

Thus we will hurt small business and help big business.

95 CoNG. REC. 11,487 (1949); see also Senate Hearings, supra note 34, at 206 (statement of George S. Eaton, Executive Secretary, National Tool and Die Manufacturers Association); House Hearings, supra note 34, at 45 (statement of Gilbert Montague, attorney, New York, N.Y.); id. at 83 (statement of Robert E. McMath, Vice President, Bethlehem Steel Corp., Bethlehem, Pa.).

36. Pub. L. No. 63-212, 38 Stat. 730 (1914), (codified as amended at 29 U.S.C. $\$ \S 52,53$ and scattered sections of 15 U.S.C. and 18 U.S.C. (1982 and Supp. V 1987)).

37. See Lande, supra note 27, at 109, 128, 133-34; Scherer, supra note 30, at 977 n.20; $f$. Stigler, The Economists and the Problem of Monopoly, 72 AMER. ECON. REv. PAPERS \& Proc. 1 (1982) (explaining the views of economists when Congress passed the antitrust acts).

Nobel Laureate Paul Samuelson reflected on the state of knowledge of the evil of prices above the competitive level (where price equals marginal cost) in the economics profession during the mid1930s, before pathbreaking work by the late Abba P. Lerner: "I can testify that no one at Chicago or Harvard could tell me in 1935 exactly why $P=M C$ was a good thing, and I was a persistent Diogenes." Samuelson, A.P. Lerner at Sixty, 31 REV. Econ. STUD. 169, 173 (1964).

38. Celler-Kefauver Amendment, Pub. L. No. 81-899, 64 Stat. 1125 (1950) (codifled as amended at 15 U.S.C. $\$ \S 18,21$ (1982 and Supp. V 1987)).

39. Our search of the legislative histories of the Clayton Act and Celler-Kefauver Amendment revealed neither explicit nor implicit evidence of a congressional concern with allocative inefficiency arising from monopoly pricing. See Fisher \& Lande, supra note 5, at 1589-90; Lande, supra note 27, at 130-42. Nor have scholars advocating a strong efficiency orientation to the legislation produced such evidence. See, e.g., Muris, supra note 5, at 393-402 (arguing that the absenee of such evidence does not mean that Congress intended to exclude any concern with efficiency). 
evaluating a merger. ${ }^{40}$ Assume a merger that simultaneously increases both market power and efficiency. Enhanced market power enables firms to raise prices from $P_{1}$ to $P_{2}$ despite lower marginal costs. ${ }^{41}$ Area $C$ shows the efficiency gain, the reduced cost of producing quantity $Q_{2}$. Area $S$ shows a wealth transfer from consumers to firms that acquire market power from the merger. The loss to consumers, however, is the sum of areas $\mathrm{S}$ and $\mathrm{D}$. The consumers' loss of $\mathrm{S}$ is obvious; what the consumers lose the sellers gain.

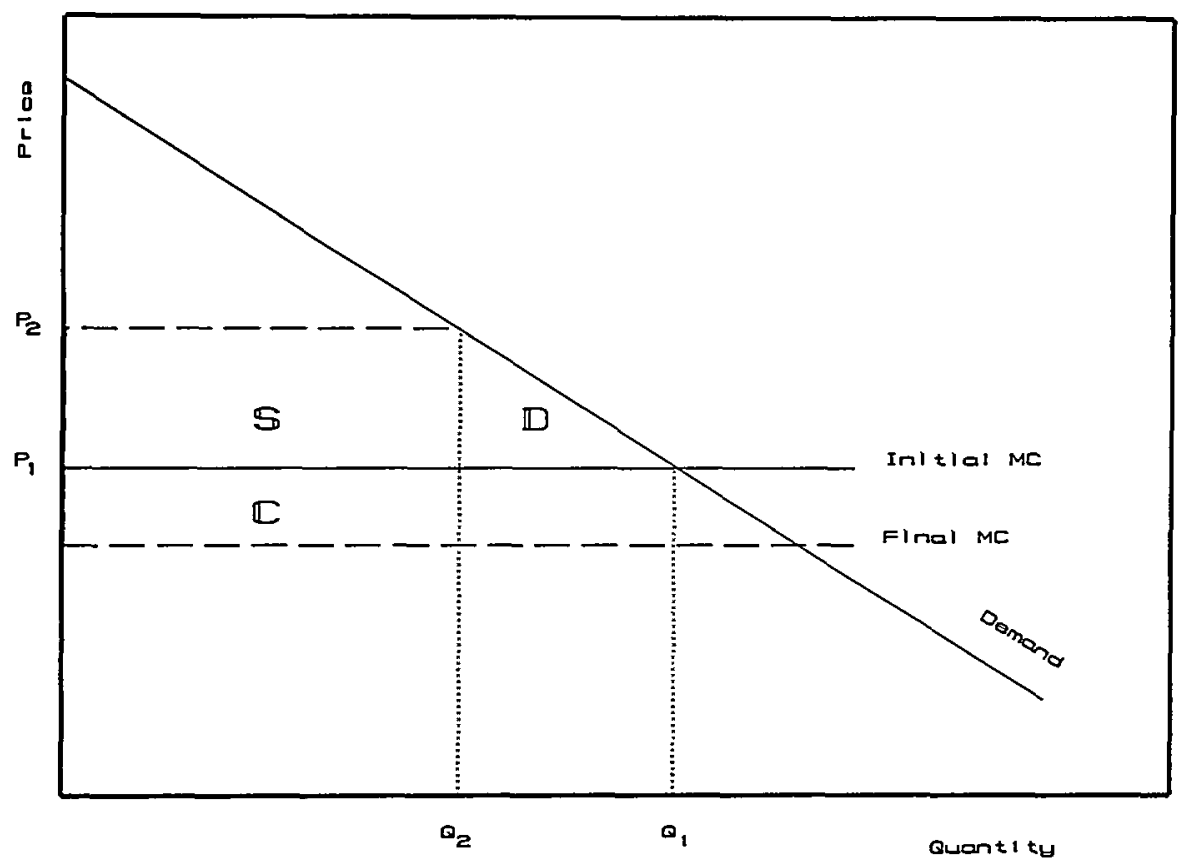

FIGURE 1

Area $D$, the allocative inefficiency, is less obvious. For all quantities between $Q_{2}$ and $Q_{1}$, consumers would be willing to pay more than the cost to society of the inputs used to produce the product. However, because the sellers would have to lower their prices on all units, including those they could have sold for a higher price, it is unprofitable for them

40. Williamson, supra note 5 , at 21 , originated this diagram. See Fisher \& Lande, supra note 5 , at 1624-51, for a discussion of a host of ambiguities and qualifications to this simplified ("naive," to use Williamson's characterization) formulation of the tradeoff problem. Williamson, supra note 5, at 21 , assumed constant marginal cost (MC), and we maintain that assumption for consistency. The more general shape for MC, which we use in Figure 2, adds complexity that is not necessary to illustrate the basic tradeoff issues.

41. A merger that helps a firm maintain its market share and supracompetitive prices may be objectionable even if it does not lead to higher prices. Krattenmaker, Lande \& Salop, Monopoly Power and Market Power in Antitrust Law, 76 GEO. L.J. 241, 258 (1987). 
to produce more than $\mathrm{Q}_{2}$. Because the loss to consumers (the sum of areas $S$ and $D$ ) exceeds the gain to producers (area $S$ ), the difference, area $\mathrm{D}$, is the deadweight loss to society from the reduced output. To the advocates of the economic efficiency criterion, allocative inefficiency (area D) is the only negative result from enhanced market power; wealth transfers (area S) are irrelevant. ${ }^{42}$ The economic efficiency criterion would permit a merger likely to result in higher prices if the expected efficiency gain, $C$, exceeded the anticipated deadweight loss, $\mathrm{D}^{43}$

The legislators who passed the antimerger statutes would have disagreed with the economic efficiency approach. Congress wanted to prevent price increases to supracompetitive levels. The legislators focused on area $\mathrm{S} .{ }^{44}$ They did not realize that area $\mathrm{D}$ existed, ${ }^{45}$ and they either ignored area $\mathrm{C}$ or assumed that it would be of negligible size. ${ }^{46}$ Rather than allowing price to rise to $P_{2}$, as the economic efficiency criterion could do, a standard consistent with congressional intent would prohibit mergers in which price would be likely to rise above $P_{1}{ }^{47}$ In short, a price standard would prohibit any merger substantially likely to induce a new wealth transfer from consumers to firms. ${ }^{48}$

42. Cf. R. BoRK, supra note 7, at 91 (1978).

43. Williamson, Economies as an Antitrust Defense Revisited, 125 U. PA. L. REV. 699, 709 (1977), argued that according to his simple model this burden would not be very heavy, because cost savings of $2 \%$ would offset market-power effects from the vast bulk of mergers that one might expect. For other assessments, see supra note 5.

44. Economists define rent as all payments to inputs in excess of the minimum required to make them available to the industry or economy. See E. MANSFIELD, supra note 2, at 376-77. Since rents are in some sense excess payments, reductions in their value will not affect resource allocation. "Rent seeking" refers to the common tendency to fight over access to rents. Rent seeking could consume part or all of area S. If rent seeking wasted some or all of area S, price might have to fall before a merger would enhance efficiency. For classic discussions of rent seeking, see Posner, The Social Costs of Monopoly and Regulation, 83 J. PoL. ECoN. 807 (1975); Tullock, The Welfare Costs of Tariffs, Monopolies, and Theft, 5 WEST. ECON. J. 224 (1967).

45. See supra notes 34-36 and accompanying text. Nonetheless, proper consideration of legislative intent includes analysis of "our best judgement as to what Congress would have wished if these problems had occurred to it." Bersch v. Drexel Firestone, Inc., 519 F.2d 974, 993 (2d Cir. 1975) (opinion of Judge Friendly), cert. denied, 423 U.S. 1018 (1975). We must therefore ask what Congress would have done if it had known of the existence and importance of allocative efficiency. We believe that Congress would have included it as one of the factors in its analysis and that antitrust enforcers and courts should therefore do so as well.

46. Most legislators could ignore area $\mathrm{C}$ because they thought that there was no tradeoff. They believed that costs would probably rise, not fall, if increased market power induced prices to rise. See supra text accompanying notes 34-36.

47. One can characterize this standard either in terms of price (consumers' property rights) or output. If demand were completely inelastic within the relevant range, or if firms used certain kinds of price discrimination, however, price could increase to some consumers even though output remained constant. The wealth transfer or price label is therefore a somewhat more accurate characterization of congressional intent.

48. Fisher \& Lande, supra note 5, at 1587-98. A reasonable way to interpret the Justice Department's Merger Guidelines is to think of them as permitting a de minimis price increase of less than 5\% (1982 Merger Guidelines) or a "small but significant and nontransitory" amount (1984 Merger Guidelines), now generally reported to be 10\%. See, e.g., Briggs, An Overview of Current 
Agencies and courts should resolve the market power/efficiency tradeoff according to the primary purpose of the antimerger laws. ${ }^{49}$ Thus, the proper formulation of the tradeoff is, "How much must marginal cost decrease to offset a given increase in market power and ensure that price not increase?"so Under this approach, efficiency gains would be relevant to the extent that one expected them to affect postmerger prices. By contrast, a standard based only on economic efficiency could allow substantial wealth transfers and understate the efficiency gains that Congress would have required to offset a given increase in market power. ${ }^{51}$

Law and Policy Relating to Mergers and Acquisitions, 56 ANTITRUST L.J. 657, 681 n.1 (1987); Calkins, Developments in Merger Litigation: The Government Doesn't Always Win, 56 ANTITRUsT L.J. 855, 857 n.9, 881 n.125 (1987); Salop, Symposium on Mergers and Antitrust, 1 J. ECON. PERSP. Fall 1987, at 3, 10; Yoerg, The Use of an Economist in a Contested Merger, 56 ANTrrRUst L.J. 789, 790 (1987). One would like to investigate the percentage change in marginal cost necessary to ensure that price not rise by more than $5 \%$ or $10 \%$. See Fisher, Lande \& Vandaele, supra note 17 (in the context of competition to monopoly). We have not done so here, however, largely because it would be enormously complex to do so with our model. By focusing on equilibrium price and output and restricting the changes to keep the equilibrium values constant, we limit our examination to firstorder conditions for the merging firms. To consider a price increase would require solving the structural model for a new equilibrium, a task that in general would be very complex unless one made overly simplifying assumptions (such as constant marginal cost).

We can, however, obtain an upward-bound estimate of the percentage price increase that a merger could create if it did not lead to collusion. Assume that firms 1 and 2 merge and close down firm 1 completely. If none of the remaining firms respond by increasing output, then

$$
\begin{aligned}
& \% \text { increase in } P=s_{1} /|\eta| \text {, where } \\
& s_{1} \text { is the percentage market share of firm } 1,0 \leq s_{1} \leq 100 \text {, and } \\
& m \mid \text { is the absolute value of the elasticity of demand. }
\end{aligned}
$$

Thus, for example, with $s_{1}$ of $20 \%$ and $|m|=4$, the most one could expect price to increase would be $5 \%$. In general, one would expect remaining firms to respond to a price increase by raising their outputs. Also, one would generally expect an acquiring firm not to eliminate the acquired firm's output completely. Both these factors would typically prevent price from increasing by anywhere near as much as the equation in this note suggests. However, if a merger increased the probability of successful collusion, that is if the remaining firms reacted to the merged firm's output restriction by reducing their outputs, the percentage increase in price could be greater. See infra notes $95-105$ and accompanying text.

49. Any standard must also be workable. See infra notes 107-126 and accompanying text.

50. The Federal Trade Commission has adopted a similar standard on at least one occasion: Assuming that these cost savings can be realized, AMI does not establish that they will necessarily inure to the benefit of consumers; in fact, AMI's own economic expert has suggested the contrary. .... [I]t is unlikely that AMI can show that "market forces will oblige [AMI] to pass [cost saving efficiency gains] on to consumers." See L. Sullivan, ANTITRUST 631 (1977).

In re American Medical Int'l, Inc., 104 F.T.C. 1, $219-20$ (1984) (alterations in original) (footnote omitted); see also Oliver, supra note 3, at .238-40 (claiming that the Commission uses a price standard).

51. Although the top Reagan administration antitrust enforcers stated that they evaluated mergers solely on the basis of economic efficiency, in practice it was sometimes difficult to know whether they used economic efficiency or price. For example, the 1982 and 1984 Merger Guidelines both focus on the ability of an imaginary monopolist or cartel to impose a " small but significant and nontransitory" increase in price" as the basis for market definition, entry barriers, collusion, and other factors in the analysis of a merger. To our knowledge, neither the Antitrust Division nor the 


\section{III}

\section{Effects of EfFiciency Gains on Price}

Firms maximize profits by producing goods at the level of output where marginal revenue equals marginal cost. Firms therefore increase their outputs and reduce their prices as efficiency gains lower their marginal costs. ${ }^{52}$ Some efficiency gains, however, reduce fixed costs, not shortrun marginal or variable costs. ${ }^{53}$ Reductions in fixed costs lower a firm's total costs and increase its profits but change neither its marginal cost nor marginal revenue. For that reason, reductions in fixed costs in the short run neither lower prices for consumers nor induce firms to increase output. $^{54}$ Thus a merger that only reduces the combining firms' overhead costs immediately benefits those firms, but not their customers. If merger policy focuses on price changes, efficiency gains that only affect fixed costs will seldom justify an otherwise anticompetitive merger.

In contrast, efficiency gains that lower marginal costs immediately benefit consumers by encouraging firms to increase their rates of output and reduce their prices. These efficiency gains occur when the merging firms successfully combine the best attributes of each and thereby lower their marginal cost schedules. ${ }^{55}$ We examine this type of efficiency more closely in our modeling.

Commission has ever publicly stated that it had declined to challenge a particular merger, despite the expectation of higher prices, because of sufficient anticipated efficiency gains. Even if the Assistant Attorney General or the Federal Trade Commission decided not to challenge a particular merger on this basis, admitting so publicly would entail obvious political risks.

52. If firms have any market power, they can sell more goods only by lowering their selling prices. If firms have no market power, they take prices as given and set their outputs where marginal revenue equals marginal cost. However, if enough firms in a competitive market become more efficient and expand their rates of output, total output will increase and price will fall.

Mergers can also lead to inefficiency, which also has varying effects on final product prices. This inefficiency is usually unanticipated, so we cannot analyze its probable effect on prices, even in theory, except in hindsight. See Fisher \& Lande, supra note 5, at 1599-1604, for a more extensive discussion of the efficiency and inefficiency effects of mergers.

53. Some cost reductions to a firm are not legitimate efficiency gains since they are not resource savings but represent wealth transfers or contravene public policy. For this reason, we do not consider tax savings or evasion of regulations to be legitimate efficiency gains and therefore do not analyze them.

54. See, e.g., C. Baird, Prices and Markets: Microeconomics 74-79 (1975). In the short run, a firm equates short-run marginal cost with marginal revenue. In the long run, it equates longrun marginal cost with marginal revenue. Reductions in fixed cost may reduce long-run marginal cost but do not affect short-run marginal cost. For that reason, fixed cost efficiency gains generally affect prices only indirectly. For example, a merger that lowered average cost three percent by reducing fixed cost would only affect output and pricing decisions indirectly, in the long run.

55. Such a merger would decrease marginal cost for a given level and rate of output. See A. Alchian \& W. Allen, UNiversity Economics Elements of INQuiry 255-78 (3d ed. 1972) (discussing the separate effects of rate and level of output on costs). The difference between a change in cost schedules and a movement along an unchanged cost schedule is analytically the same as the difference between a change in demand and a movement along an unchanged demand curve. See $\mathrm{E}$. MANSFIELD, supra note 2, at 87 (explaining this distinction).

A merger may create opportunities to increase efficiency by making organizational changes 
Two other types of merger-specific efficiency gains can generate benefits analogous to decreases in marginal costs. Rationalization of production can allow the merged firm to produce the same amount at lower total cost by shifting output to the plant with the lower marginal costs. ${ }^{56}$ By shifting production among plants until it equalized marginal costs, a firm could lower overall costs even if the underlying marginal cost schedules remained unchanged. ${ }^{57}$

Finally, a horizontal merger may enable a firm to achieve economies of scale without changing its marginal cost for a given rate and level of

within the combined firm. See Williamson, The Modern Corporation: Origins, Evolution, Attributes, 19 J. ECON. LITERATURE 1537 (1981).

56. Further, if two firms perceived marginal cost differently (given imperfect information), they would not produce at the same marginal cost even if they perceived their marginal revenues to be the same. If the two firms merged and decided to produce the same level of output, they could do so at a lower total cost by shifting outputs between plants to equalize marginal costs.

Under most oligopoly models, firms perceive different marginal revenue curves. Firms might face different marginal revenue curves because of differences in consumers' preferences for each's product. However, if the two products could be manufactured on the same equipment, the merged firm would still lower overall costs by rationalizing production, to equate marginal costs at the two facilities.

57. Figure 2 demonstrates that any such efficiency gains would be small. Suppose that both of the merging firms faced the same marginal cost (MC) curve but that firm 1 had initially perceived a lower marginal revenue (MR) curve than had firm 2 . As a consequence, firm 1 would have produced output $x_{1}$ and firm $2, x_{2}$, where $x_{1}<x_{2}$. Rationalization of their joint output would require each to produce $\bar{x}=\left(x_{1}+x_{2}\right) / 2$. Firm 1's costs would increase by area A; firm 2's would fall by area $B$. Area $(B-A)$ approximates the net savings. The two firms' perceptions of marginal revenue would

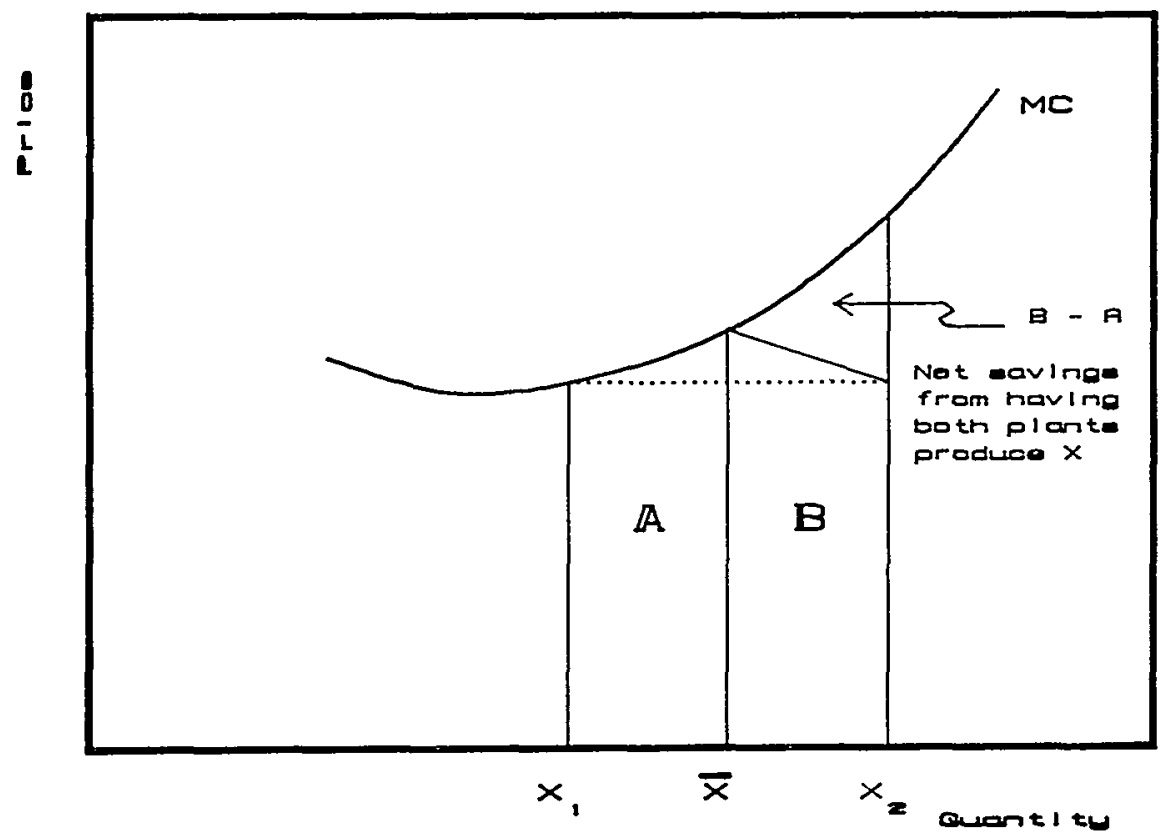

FIGURE 2 
output. By combining production, firms whose levels of output would otherwise have been small in relation to ininimuun efficient scale can increase their overall level of output and thereby decrease inarginal cost. Alternatively, multiproduct firms with large econoinies of scale in relation to demand inay generate merger-specific savings by having each previously diversified plant specialize in part of the overall product line. Although we focus on downward shifts in an upward-rising marginal cost curve, scale econoinies are an equally valid benefit from inerger. ${ }^{58}$ Our tradeoff calculations therefore apply to scale econoinies as well as to other types of efficiency gains that reduce marginal costs for a given rate and level of output. ${ }^{59}$

\section{IV}

\section{The Tradeoff in Various Types of Markets}

\section{A. The Tradeoff Under Competition and Monopoly}

The tradeoff between market power and efficiency obviously depends on the nature of and changes in market structure and behavior. The extreme situations are the easiest to describe, inodel, and evaluate.

A merger in an industry with essentially coinpetitive pricing usually leaves pricing unaffected. Thus, if a merger creates no exploitable inarket power in an essentially coinpetitive industry, there is neither a wealth transfer nor an allocative inefficiency cost. In such a case, there is no justification for challenging the inerger under either a price or an efficiency standard. The Departinent of Justice Merger Guidelines therefore

probably not differ substantially, so any savings from rationalization would tend to be small.

For example, suppose that firms 1 and 2 face the same $\mathrm{MC}$ curve but have different perceptions of $M R$ and thus have [output, $M C]$ combinations of $\left[x_{1}, M C_{1}\right]$ and $\left[x_{2}, M C_{2}\right]$. Figure 2 reveals that the savings in total cost from output rationalization would approximate:

Savings $\approx 1 / 4 \triangleleft \mathrm{MC} \Delta x$,

where $\Delta \mathrm{MC}=\left(\mathrm{MC}_{2}-\mathrm{MC}_{1}\right)$ and $\Delta x=\left(x_{2}-x_{1}\right)$. Total cost is Average Total Cost (ATC) $\cdot x ;$ if $\mathrm{MC} \approx \mathrm{ATC}$, then $\mathrm{MC} \cdot \boldsymbol{x}$ approximates total cost. The ratio of cost savings to total cost is approximately:

$(1 / 4) \epsilon_{\mathrm{s}}(\wedge \mathrm{MC} / \mathrm{MC})^{2}$,

where $\left.\epsilon_{\mathrm{s}}=(\triangleleft x / x) /(\lrcorner \mathrm{MC} / \mathrm{MC}\right)$ is the elasticity of the $\mathrm{MC}$ curve. Consequently, even a large difference between $\mathrm{MC}_{1}$ and $\mathrm{MC}_{2}$ would generate very small cost savings from output rationalization. If, for example, $\mathrm{MC}_{2}$ exceeded $\mathrm{MC}_{1}$ by $20 \%$, the cost savings would be only $1 \%$ for $\epsilon_{\mathrm{s}}=1$.

58. But exploitation of economies of scale may not always be convenient, at least in the short run. For example, if the plants of the merging firms were both too small to exploit economies of scale, the combined firm would need to replace the existing facilities with a new, larger facility to exploit scale economies. Moreover, merger is not always necessary or sufficient to exploit economies of scale. Unless brand preferences prevented it, one of the firms might have been able to expand on its own, without a merger, and force smaller, inefficient plants out of the market. Therefore, merger is not always necessary or sufficient to exploit economies of scale.

59. We defer consideration of a fifth type of efficiency: improvement in quality or product variety for the same level of costs. See infra notes 116-127 and accompanying text. 
state that the government is highly unlikely ever to challenge a merger that does not significantly alter the structure of an essentially competitive mdustry. ${ }^{60}$ Indeed, the government has closely examined fewer than $10 \%$ of all mergers reported under the Hart-Scott-Rodino Act ${ }^{61}$ and challenged or negotiated restructurings in only a small proportion of those it has investigated. ${ }^{62}$

Conversely, challenge is obviously appropriate in the rare case when a merger would be likely to transforin an industry froin competitive to perfectly collusive (or monopolistic) pricing. This case assumes the maximuin possible anticoinpetitive effect and therefore gives a maximuin estimate of the percentage reduction in marginal costs necessary to offset any possible increase in market power and keep price constant. The required cost reductions would be quite extreme, from $10 \%$ to $50 \% .^{63}$

\section{B. The Tradeoff Under Oligopoly: Decision Criteria and Economic Models}

Firıns rarely propose mergers to monopoly since the government is virtually certain to challenge such mergers. ${ }^{64}$ Enforcement therefore generally focuses on oligopolistic markets-those in which firms have large enough market shares to react to and affect each others' pricing and output decisions. In these markets, prices remain between the purely competitive and purely monopolistic levels. The difficult enforcement questions concern intermediate cases, where a inerger may shift an industry from coinpetitive to oligopohistic or from one oligopolistic equilibrium to another. Here, balancing increased inarket power against increased efficiency is likely to be the most difficult.

Unfortunately, economists disagree about how to inodel oligopoly, ${ }^{65}$ and different models predict widely divergent effects on prices for a given

60. See, e.g., 1984 Merger Guidelines, supra note 23, at $\$ \S 3.11,3.3$, and 1982 Merger Guidelines, supra note 21 , at $\S \S \operatorname{III}(\mathrm{A})(1)$, III(C), for two examples: unconcentrated markets and markets where entry conditions are easy. The Merger Guideline standards are below the levels at which researchers have frequently found significant anticompetitive effects. See generally Pautler, $A$ Review of the Economic Basis for Broad-Based Horizontal Merger Policy, 28 ANTITRUST BuLL. 571 (1983). However, Congress also wanted to prevent price effects in their incipiency. See Fisher \& Sciacca, An Economic Analysis of Vertical Merger Enforcement Policy, 6 REs. L. \& EcoN. 1, 47-48 (1984).

61. Hart-Scott-Rodino Act, 15 U.S.C. $\S 18$ a (1982).

62. For a discussion of the number of Hart-Scott-Rodino filings, requests for additional information, and government challenges or induced restructurings in recent years, see Jorde, supra note 23, at 592 n.40; see also supra note 1.

63. See infra notes $98-101$ and accompanying text.

64. See supra note 17.

65. For example, Scherer devotes four chapters and more than 100 pages to a discussion of different models of oligopoly behavior. F. Scherer, INDUSTR1AL MARKET STRUCTURE AND Economic Performance 151-266 (2d ed. 1980). 
structural change (change in market parameters). ${ }^{66}$ Even if economists could agree on a single model, they would rarely know the correct parameter values for a given market. Relatively small changes in the underlying assumptions or in values of important economic or psychological parameters can change the predictions substantially. Moreover, there is no direct and well accepted link between concentration levels and changes and the likelihood of a market experiencing interdependent (but noncooperative) or collusive oligopolistic pricing. ${ }^{67}$ Given the inability of economists to predict market power effects of mergers accurately, we obviously cannot estimate precisely how great efficiency gains would have to be to offset the effects from any given merger.

Professor Ohiver Williamson's pathbreaking analysis of efficiency and market power effects provided a framework for all subsequent analyses of the percentage by which costs must decrease to compensate for expected allocative inefficiency from market power effects. ${ }^{68}$ Our approach differs from Williamson's in two important respects. While Williamson only considered economic efficiency, ${ }^{69}$ our criterion is that the efficiency gain be sufficient to prevent price from rising and thus output from falling. Also, Williamson's approach, and the tradeoff calculations attributed to it, assume implicitly that efficiency gains would reduce marginal costs for all firms in the industry, not only for the merging parties. $^{70}$ We explicitly differentiate the effects of marginal and fixed cost efficiency gains and whenever possible assume that any efficiency gains accrue only to the merging firms.

Our analysis also assumes that premerger prices are at the competitive level. When the premerger price is supracompetitive, the analysis becomes much more complex. ${ }^{71}$

66. For example, theoretical models generally predict a gradual increase in market power and thus in price as the number of firms decreases or concentration increases. Some empirical studies, in contrast, tentatively suggest a range of essentially competitive pricing followed by an abrupt increase to essentially monopolistic pricing. L. Fouraker \& S. SIEGEL, BARGAining Behavior (1961); Dolbear, Lave, Bowman, Lieberman, Prescott, Rueter \& Sherman, Collusion in Oligopoly: An Experiment on the Effect of Numbers and Information, 82 Q.J. Econ. 240 (1968); Kwoka, The Effect of Market Share Distribution on Industry Performance, 61 REv. ECoN. \& STAT. 101 (1979); Kwoka \& Ravenscraft, Cooperation vs. Rivalry: Price-Cost Margins by Line of Business, 53 EcoNomiCA 351 (1986).

67. For an extensive compilation of the evidence on the relationship between concentration and profits, and the meaning of this evidence for merger policy, sec Pautier, supra note 60 .

68. Williamson, supra note 5. See Fisher \& Lande, supra note 5, for a detailed discussion of Williamson's analysis and the subsequent literature.

69. See supra note 5 .

70. Fisher \& Lande, supra note 5 , at 1627 n.175. Williamson recognized this problem and proposed a weighting adjustment to account for differences in the percentages of the industry subjeet to the price and cost changes. See Williamson, supra note 5, at 27 . However, authors of mathematical solutions to the tradeoff have not taken this subtlety into account. For a discussion of these studies, see Fisher \& Lande, supra note 5, at 1624-50.

71. See Fisher \& Lande, supra note 5, at 1627 n. 175, 1640 n. 208, 1641 n. 209, 1642 n. 212. 
Appendix A explains in detail the oligopoly models that we sketch and summarize here. We initially assume that firms operate independently-i.e., without colluding. ${ }^{72}$ The use of a price standard simplifies the modeling, because we need compare only equilibrium situations at an unchanged output (since price does not change). Because we only examine conditions at an equilibrium output level, we do not need restrictive assumptions about the shapes of the cost and demand curves, as we would if we were examining behavior under the economic effciency criterion (where output and price change). ${ }^{73}$

\section{Oligopoly: A Range of Possibilities}

The market power effects of a inerger in oligopoly depend on the firms' subjective evaluations of how other firms would react to changes in their prices and outputs ("conjectural variations"), the market shares of the merging firms, and the elasticity of demand.

\section{Conjectural Variations}

Conjectural variations have two components: specific assumptions ${ }^{74}$ about the nature of each firm's conjectures, and a model ${ }^{75}$ of how each firm's conjectures change in response to a merger. Most ohgopoly models place restrictive and frequently unjustified limitations on the values of their parameters (such as conjectural variations and elasticity of demand)

72. We relax this assumption infra at notes 95-105 and accompanying text.

73. To use an economic efficiency criterion, one must examine the effects of changes in prices and output levels. Such model building would be vastly more complex than model building for an unchanged output and would also require restrictive (perhaps unrealistic) assumptions of the behavior of marginal cost and marginal revenue as output changes. This complexity underlies our finding that the price criterion is simpler and more workable than the economic efficiency standard in the context of oligopoly.

74. A common approach to oligopoly model building is to specify certain assumptions, usually Cournot. Cournot assumptions are the least competitive among noncooperative oligopoly assumptions. All oligopoly assumptions that are less competitive than Cournot involve some degree of cooperation-collusion-among firms. Under Cournot assumptions, each firm predicts that its rivals would not replace any shortfall in its production (tlrat is, rivals would not react to any changes in its output). Competitive assumptions are the opposite (that is, the most competitive): eacli firm predicts that its rivals would replace all shortfalls. Under intermediate noncooperative oligopoly assumptions, each firm predicts that its rivals would replace some but not all of its decrease in output. Since Cournot assumes a particular value for eacli firm's prediction of its rivals' response, it is a special case of a more general oligopolistic treatment, discussed infra at text following note 76.

For an example that treats collusive beliavior in a similar way, see J. Kwoka, The Private Profitability of Horizontal Mergers with Non-Coumot and Maverick Behavior (1989) (Unpublished manuscript, George Washington University) (on file witl the autliors).

75. "Model" might have two distinct meanings: the nature of firms' conjectures or the way their conjectures change in response to a merger. We use "assumptions" to refer to the first meaning and "model" to describe the second. We use "model building" to describe the entire process of developing integrated models and assumptions to describe a market. 
to make the computations more manageable. These restrictive assumptions can generate misleading estimiates of the tradeoff between market power and efficiency gains. ${ }^{76}$ To minimize this source of bias, we develop an approach that provides the most general expression of how extensive efficiency gains must be to prevent mergers from leading to higher prices. We investigate four plausible models of the effects of inerger on conjectural variations and then simulate the reaction of the market over the full reasonable range of conjectural variations, from competitive to Cournot. ${ }^{77}$ Since our inodel building does not rely on any single theory of oligopoly but embraces the full range of noncooperative oligopoly behavior, we call our treatment "theoretically neutral." The price of this neutrality is answers that are less precise, but more plausible, than those that models with highly restrictive assumptions would generate.

\section{Market Concentration}

The relevant range for market concentration-levels is that for which a case-by-case efficiency defense could determine the ultimate legality of a merger. The Merger Guidelines express concern only for relatively large mergers im markets that the Department defines as inoderately or highly concentrated. The Department uses the Herfindahl-Herschman Index (HHI) to measure market concentration and defines an industry as moderately concentrated if its HHI is between 1000 and 1800 and highly concentrated if its HHI exceeds $1800 .{ }^{78}$ We therefore surveyed all proposed horizontal mergers with a postmerger HHI in excess of 1000 for

76. For example, one noted authority said of Cournot, supra note 74:

One of the most telling criticisms of Cournot's analysis has been that his players learn very slowly. At each stage they change their own allocations assuming the opponent will not change his; and at each stage their assumptions prove wrong because every change provokes an answer. A satisfactory theory should respond to this charge, for if the equilibrium point $\left(x^{*}, y^{*}\right)$ is to be regarded as the solution of something, it should result from some more enlightened behavior on the players' parts than an infinite sequence of bad guesses!

J. CASe, Economics ANd the Compertivive Process 30 (1979) (endnote omitted). Case continues with additional criticisms of Cournot assumptions. Id. at 30-31.

77. Our four models assume respectively that conjectures do not change, that they change in proportion to the portion of the market that the firm does not control, that they change in proportion to market concentration, and that they change as the number of firms changes. For details, see Appendix A.

78. One calculates the HHI by summing the squares of the individual market shares of all the firms in the market. See, e.g., F. SCHERER, supra note 65 , at 58. Since economists, including Scherer, calculate the HHI as ranging between 0 and 1.0, they implicitly use fractional market shares. The Justice Department, however, interprets market shares as percentages ranging from 0 to 100 , drops the decimal, and defines the $\mathrm{HHI}$ range as 0 to 10,000 . This stylistic difference does not affect the interpretation of the HHI.

For highly concentrated industries (those defined as having a postmerger HHI of more than 1800 ), the Department ignores mergers causing a change in the HHI of 50 points or less; for moderately concentrated industries (those defined as having a $\mathrm{HHI}$ of 1000 to 1800 postmerger), the trigger is a change of 100 points. The trigger points indicate when the Department is likely to 
which the Federal Trade Commission requested additional information under the Hart-Scott-Rodino provisions during the period June 14, 1982 (when the Reagan administration issued its first Merger Guidelines) through the end of $1986 .{ }^{79}$ We then selected the HHI values for the nineteen of these proposed inergers for which the staff of at least one of the Coininission's bureaus believed that efficiency gains would be reasonably tikely.

Table 1 summarizes the data for this group of inergers. The data deinonstrate that the enforceinent agencies frequently evaluate inergers with projected HHI changes of several hundred and that changes of 500 to 1000 or inore are reasonably common. ${ }^{80}$ Based on these data, we

challengc a merger, in the absence of other factors indicating that the merger is unlikely to have anticompetitive effects. See 1984 Merger Guidelines, supra note 23, at $\S 3.11$; 1982 Merger Guidelines, supra note 21 , at $\$$ III.A.1. Recent enforcement standards are probably more lenient than those in the Merger Guidelines. See infra notes 80, 135.

79. In 9 of the 19 mergers, the staffs of both the Bureau of Competition (attorneys) and the Bureau of Economics (economists) found the efficiency arguments convincing; in the remaining 10, the staff of only one of the bureaus found the arguments convincing. The data set consists of 70 of the 76 horizontal mergers and joint ventures during the period for which the Commission issued requests for detailed information ("second requests") under the Hart-Scott-Rodino provisions. We excluded only the 3 joint ventures and 3 mergers in which the staffs of both bureaus predicted that the postmerger HHI would be less than 1000 . We thank Malcolm Coate for making available the data set that he compiled for the Commission.

Staff memos do not always distinguish savings in marginal costs from decreases in fixed costs when discussing anticipated efficiency gains. Nor do they always follow the Merger Guidelines, which require "clcar and convincing evidence" that the anticipated efficiency gains would be likely. See 1982 Merger Guidelines, supra note 23, at § V.A.; 1984 Merger Guidelines, supra note 21, at $\S 3.5$. In addition, the memos seem inconsistent in their searches for less anticompetitive methods to achieve the desired cost savings.

Our focus on efficiency gains and HHIs is obviously incomplete. For example, some markets with high HHI levels and changes did not present any anticompetitive problem because of easy entry conditions. For that reason, prospective efficiency gains probably determined the outcomes of proposed mergers in fewer than ten of the instances in this sample. The Commission challenged many but not all of the 19 mergers in our sample. To protect the confidentiality of the Commission's decision process, we do not report the number of challenges.

80. Publicly available data for 31 markets in 22 recent mergers, as reported in Briggs, supra note 48 , at 713-29, show a similar pattern. Among mergers that the Commission evaluated, the postmerger HHI ranged from 1166 to $8000+$, with a mean of 4311 and a median of 3500 . The change in the HHI ranged from 0 to $3900+$, with a mean of 1246 and a median of 825 . Among mergers that the Department of Justice evaluated, the postmerger HHI ranged from a low of 1747 to a high of 9856 , with a mean of 4354 and a median of 3579 . The change in the HHI ranged from 240 to 3977 with a mean of 1175 and a median of $900+$. Since concentration data generally become publicly available only when an agency challenges a merger, the markets in this sample are probably not representative of those affected by mergers that the agencies evaluate closely (that is, issue a "second request" for information under the Hart-Scott-Rodino provisions; see supra note 79). Moreover, we do not know which of these mergers included credible claims of merger-specific efficiency gains.

In tabulating the Briggs data, we made conservative approximations in some cases. For example, where a number was reported as " $900+$ " or " $3900+$," we dropped the " + " in calculating the means. Also, we used 250 in one merger where the change in the HHI was reported as lying between 200 to 300 .

The lowest change in HHI among mergers the Commission evaluated (zero) resulted from a 


\section{TABLE 1 \\ Concentration Levels and Changes For MERgers With Serious EFFiciency Claims $\dagger$}

Bureau of Competition Staff

Postmerger Change in HHI the HHI

Group $1 \ddagger$ (June 1982-March 1985)

\begin{tabular}{lc} 
Low & 1508 \\
High & 2574 \\
Mean & 1989 \\
Median & 1929 \\
Group 2f (April & 1985 -December 1986) \\
\hline Low & 1223
\end{tabular}

\begin{tabular}{ll}
\hline Low & 1223 \\
High & 5041
\end{tabular}

Mean

2942

Median

2662

Total Sample

\begin{tabular}{ll}
\hline Low & 1223 \\
High & 5041 \\
Mean & 2541 \\
Median & 2172
\end{tabular}

Bureau of Economics Staff

$\begin{array}{ll}\begin{array}{c}\text { Postmerger } \\ \text { HHI }\end{array} & \begin{array}{c}\text { Change in } \\ \text { the HHI }\end{array}\end{array}$

1005

109

$2290 \quad 339$

$1755 \quad 238$

$1921 \quad 236$

$154 \quad 1223 \quad 150$

$2100 \quad 5041 \quad 2121$

$656 \quad 2894 \quad 606$

$\begin{array}{lll}597 & 2662 & 538\end{array}$

$154 \quad 1005 \quad 109$

$2100 \quad 5041 \quad 2121$

$502 \quad 2414 \quad 451$

$308 \quad 2177 \quad 304$

Source: Confidential memoranda to the Federal Trade Commission during June 1982December 1986; see the description in the text accompanying notes 79 and 80 . We thank Malcolm Coate for sharing this data set, which he compiled for the Commission.

Table 1 and the accompanying analysis rely on nonpublic information from Fcderal Trade Commission internal files. Mr. Fisher obtained access to the underlying data as a Commission employee. The Commission's General Counsel authorized publication of these summary statistics under $\S 5.12$ (c) of the Federal Trade Commission Rules of Practice, 16 C.F.R. $\S 5.12(\mathrm{c})$.

Notes:

$\dagger$ The data are from 19 of the 70 horizontal mergers with predicted postmerger HHI levels in excess of 1000 for which the Commission requested additional information during this period under Hart-Scott-Rodino provisions, supra note 1 . Among those 70 mergers, the data set includes all proposed acquisitions in which the Bureau of Competition or Bureau of Economics staff judged that significant merger-specific efficiency gains were a reasonably likely result. There is no way to verify when, if at all, the Commission shared this judgment.

Merger decisions include factors other than concentration and anticipated efficiency gains; entry conditions and factors that influence the ability to collude are two of the most important. To help preserve the Commission's confidentiality, we have not reported any information on these factors, and we have not reported the Commission's resolution. The Commission challenged a large proportion of the 19 mergers in this sample.

† Group 1 includes mergers for which the Commission issued a request for additional information from June 1982 to March 1985. Group 2 includes mergers for which the Commission issued a request for additional information from April 1985 to December 1986. Since a request for additional information comes 15 to 30 days after firms file Hart-ScottRodino documents, these data indicate that firms proposed more mergers with noticeably higher market shares beginning approximately in March 1985.

There were 8 mergers in Group 1 and 11 in Group 2. For Group 1, the median is the average of the fourth and fifth highest values. 
simulated the market power/efficiency tradeoff for HHI changes of 100 , 200,500 , and 1000 .

\section{Elasticity of Demand}

The Merger Guidelines' market definition methodology determines the plausible range for elasticity of demand for relevant products. ${ }^{81}$ The Merger Guidelines define a relevant antitrust market as "a product or group of products and a geographic area in which it is sold such that a hypothetical profit maximizing" cartel would raise price by a designated percentage. ${ }^{82}$ The Department initially defined relevant markets as those in which a cartel could inipose a five percent price rise; in the 1984 revision, the Department replaced five percent with an unspecified "small but significant and nontransitory increase in price." 83 Outside observers report that the Department has recently adopted a $10 \%$ test, reportedly the level that the Departinent's economists had initially proposed. ${ }^{84}$

Selection of a permissible price increase determines the relevant range for elasticity of demand. ${ }^{85}$ For an initially competitive inarket, the relevant range for $|\eta|$ would be 5 to 11 for a $10 \%$ test and 10 to 21 for a $5 \%$ test. ${ }^{86}$ If $|\eta|$ were less than these levels, the hypothetical cartel could increase price by more than the designated 10 or $5 \%$. In terms of the Merger Guidelines, the proposed market would be too broad and should be redefined to include fewer products. ${ }^{87}$ If $|\eta|$ exceeded these levels, the hypothetical cartel could not increase price by the designated percentage.

potential competition complaint (B.A.T Industries) issued May 13, 1980 and dismissed Dec. 17, 1984. See In re B.A.T Industries, 104 F.T.C. 852 (1984). The next smallest change in the HHI was 125 for one of six markets challenged in L'Air Liquide.

81. The elasticity of demand for a product defines the percentage by which a hypothetical cartel could increase price for a given effect on sales. It is the percentage change in the quantity demanded that would result from a given percentage change in price $(\% \wedge \mathrm{Q} / \% \wedge \mathrm{P})$. The universal abbreviation for elasticity of demand is the Greek letter eta $(\eta)$. Since price and amount demanded change in opposite directions along a demand curve, $\eta<0$. Many economists, however, drop the negative sign. For clarity, we specify $|\eta|$.

82. 1984 Merger Guidelines, supra note 23, at $\S 2.0$. Compare 1982 Merger Guidelines, supra note 21, at § II.A., with 1984 Merger Guidelines, supra note 23, at $\$ 2.0$.

83. 1982 Merger Guidelines, supra note 21, at § II.A; 1984 Merger Guidelines, supra note 23, at $\S 2.0$.

84. "The economists at the Department of Justice had favored a 10 percent, two-year test (which would still be my preference) ...." White, Antitrust and Merger Policy: A Review and Critique, 1 J. ECON. PERSP. Fall 1987, 13, 15; supra note 48.

85. For a thorough treatment, see Johnson, Market Definition Under the Merger Guidelines: Critical Demand Elasticities, forthcoming in 12 RESEARCH IN LAW AND ECONOMICS (1989).

86. For an initially competitive market with constant costs and a linear demand, a cartel could increase price by $10 \%$ if $|\eta|$ equalled 5 and by $5 \%$ if $|\eta|$ equalled 10 . For constant elasticity of demand and constant costs, a cartel could increase price by $10 \%$ if $|\eta|$ equalled 11 and by $5 \%$ if $|\eta|$ equalled 21. Id.

87. See 1984 Merger Guidelines, supra note 23 , at $\S 2.11$. 
In terms of the Merger Guidelines, the proposed market would be too narrow and should be redefined to include more close substitutes. ${ }^{88}$

For above-Guidehne mergers, where oligopoly is the relevant operating assumption, the critical elasticities of demand are lower. For example, for constant elasticity of demand, the critical elasticity of demand is about $20 \%$ lower for a Cournot equilibrium with a premerger $\mathrm{HHI}$ of 2500 than for a premerger competitive market-8.5 for a $10 \%$ test and 16 for a 5\% standard. ${ }^{89}$ Taking into account increasing costs as well, ${ }^{90}$ a more realistic range for $|\eta|$ is 2 to 5 for a $10 \%$ rule and 5 to 10 for a $5 \%$ rule. We therefore evaluated the effects of mergers in our oligopoly models for $|\eta|$ of 2,5 , and 10.

Given the relevant values for the change in the HHI and elasticity of demand and our four models of the effects of merger on firms' conjectures, we were able to simulate the merger-specific efficiency gains (percentage decrease in marginal costs) neciessary to keep price from increasing. We simulated the necessary efficiency gains over a range of -1 (competitive) to 0 (Cournot) for conjectural variations, $k^{91}$ The predictions of the four models were similar. ${ }^{92}$

88. Id.

89. If we assume that a merger transforms an industry with constant marginal costs from Cournot to monopolistic pricing, the critical elasticities depend on the premerger HHI. Appendix B, section $\mathrm{E}$ shows how the critical demand elasticity varies with the premerger HHI, assuming constant elasticity of demand. Compare these results with those supra at note 86 . We provide our example here and in Appendix B for Cournot and constant elasticity of demand, the least complex to analyze formally. The result that oligopoly lowers the critical demand elasticity holds for all demand specifications, although the magnitudes vary. Because of this variation, we keep a wide range of demand elasticities for our simulations.

90. Increasing (upward-sloping) marginal costs also reduce the critical elasticity of demand. Depending on the elasticity of supply, increasing marginal costs can reduce the critical elasticity of demand by approximately 50\%. Johnson, supra note 85 . Although we have not attempted the formidable task of simulating the joint effect of increasing marginal costs and initial market power, the combined effect would presumably be to reduce the critical levels by more than $50 \%$ in comparison to an initially competitive industry with constant marginal costs.

91. For an intuitive interpretation of these values of $k$, sce supra note 74. We iterated the computations at intervals of 0.05 over this range. When possible, we assumed that both merging firms had the same values of $k$. However, this assumption would be inconsistent with Models B and $\mathrm{C}$, which assume that both firms have the same value of $k^{\prime}$ after they merge. In our simulations of Models $\mathrm{B}$ and $\mathrm{C}$, we therefore selected initial values of $k_{1}$ for the larger of the merging firms and then selected a consistent value of $k_{2}$ for the other firm. In Model D, where $k$ depends on $n$, the number of firms before the merger, we simulated over a range of $n=3$ to 9 .

The relationship between percentage change in marginal cost $(\% \wedge \mathrm{MC})$ and $k$ was very close to linear. A lincar interpolation between the minimum and maximum values of $\% \Delta \mathrm{MC}$ would therefore enable the reader to approximate $\% \triangleleft \mathrm{MC}$ for any desired value of $k$ over the interval $[-1,0]$.

92. In all cases, the relationship between the percentage decrease in marginal costs and $k$ was monotonic, and in all but a few extreme instances in Model D it was largest at $k=0$ (Cournot assumptions). In some instances, the minima in Model D were the Cournot solutions. However, these situations only occurred when the underlying model was unrealistic. The reversals occurred when there were few firms (a small $n$ ) and one of the merging firms was very small. For example, there was a Cournot minimum when there were 3 firms and the merging firms' shares were $50 \%$ and 


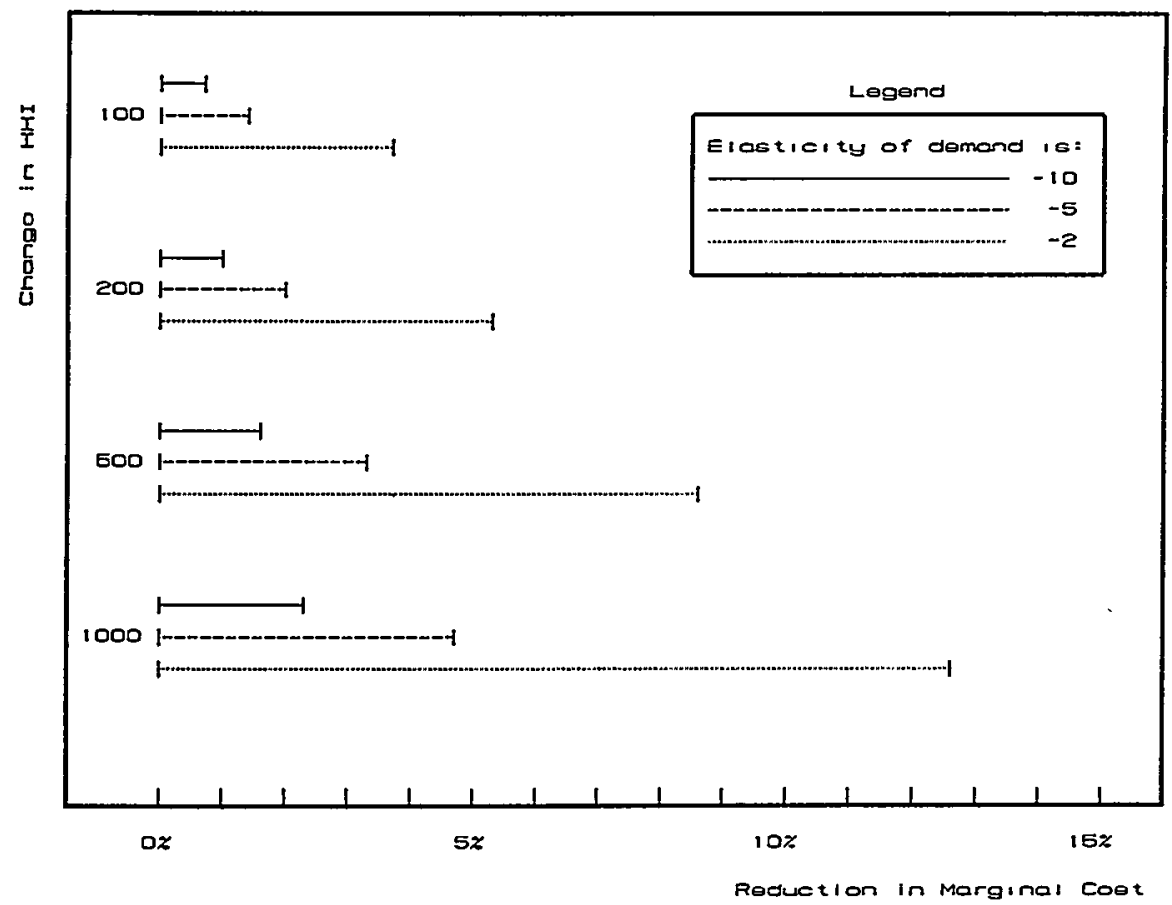

\section{FIGURE 3}

Figure 3 shows our estimates of how great the merger-specific efficiency gains must be to keep price from rising. ${ }^{93}$ The diagram shows a series of horizontal hines, each depicting a range of the percentage decrease in marginal costs necessary to prevent a price increase as $k$ increases from -1 to $0 .{ }^{94}$ This range encoinpasses all the predictions

$2 \%$. It would be unrealistic to expect both firms to have the same conjectural variations in this case, as the model implies. Model $\mathbb{D}$ therefore makes sense only when the merging firms have similar market shares. All four models gave the same percentage decrcase in inarginal costs under Cournot assumptions, because Cournot sets $k=0$ and thus $k^{\prime}=k$ for all models. Under Model $\mathrm{A}$, the smallest percentage decrcase in marginal costs was zero; for the other inodels, the sinallest percentage decrease in marginal costs was positive but generally small compared to the largest value.

93. In most cases, the merging firms would face differently shaped MC curves and would therefore have to realize disproportionate reductions in $\mathrm{MC}$ for each to continue to produce at its premerger level. The figures for \%^MC reported in Figure 3 are the averages for both firms, with each firm's requisite cost savings weighted by its premerger output. This singlc figure is inore meaningful than the two separate figures, because our primary concern is with the net output of the merged firm, not the individual outputs of the constituent plants.

$\mathrm{MR}$ and $\mathrm{MC}$ must be positive for the resulting equilibrium to be reasonable. From Equation (2) of Appendix $A$, one can easily demonstrate that this requirement is equivalent to requiring that $\left(s_{3}\right.$ $\left.+s_{2}\right)\left(1+k^{\prime}\right)<|\eta|$. By definition, $0<s_{1}+s_{2} \leq 1$. Also, since $-1 \leq k \leq 0,0 \leq\left(1+k^{\prime}\right) \leq 1$. Their product is therefore also between 0 and 1 . Since the reasonable range for $|\eta|$ is between 2 and 10 , we can be certain that MR and MC are positive.

94. Denote the premerger percentage market shares of the merging firms as [share 1, share 2]. For $\triangle \mathrm{HHI}=100$, we selected mergers from $[7.07,7.07]$ to $[10,5]$; for $\triangle \mathrm{HHI}=200$, mergers from $[10$, 
from the four models. All models predict the same maximum value for the percentage decrease in marginal costs to keep price from rising (reached under Cournot assumptions); differences arise only in the predicted necessary minimum values.

For a $10 \%$ rule and a change in the $\mathrm{HHI}$ of 500-approximately the mean for recent above-Guideline inergers in which there have been serious efficiency claims-the antitrust agencies and courts should be looking for decreases in marginal costs for the inerging firms of 0 to $9 \%$ to ensure that price not increase as a result of the merger. However, different assumptions can change the results.

\section{Varying the Assumptions: Collusion and Other Variants}

In our analysis of oligopoly so far, we have assuined that all nonmerging firms maintain the same conjectural variations (views of how they, the merging firms, and their other rivals would react to changes in output). ${ }^{95}$ The analysis becomes more complicated if we relax this assumption. If the nonmerging firms viewed the inerged firm as less rivalrous than its predecessors, the nonmerging firms might reduce their rates of production. The merged firm would then need greater cost savings than those predicted in Figure 3 to induce it to expand output to compensate for its rivals' reductions. Alternatively, the nonmerging firms might view the merged firm as a more vigorous competitor and therefore react by expanding output and reducing prices. If so, the merged firm would need smaller cost savings than those predicted in Figure 3 to ensure that industry output and price remain constant. Indeed, a merger that increased rivalry could result in price remaining constant or even falling. ${ }^{96}$

10] to $[20,5]$; for $\triangle \mathrm{HHI}=500$, mergers from $[15.81,15.81]$ to $[25,10]$; for $\triangle \mathrm{HHI}=1000$, mergers from $[22.36,22.36]$ to $[50,10]$. In some cases, more disparate market shares would have widened the range of requisite cost savings. However, including mergers involving acquired firms with market shares below 5\% stretches the credibility of the underlying assumption that the merging firms both affect price. To calculate the effects of a merger involving firms with smaller market shares, one should probably use a different model, such as the dominant firm model. For a discussion of some properties of such a model, see Mallela \& Nahata, Effects of Horizontal Merger on Price, Profits, and Market Power in a Dominant-Firm Oligopoly, 3 INT'L Econ. J. 55 (1989). Model D generated higher maxima than the other models under some unrealistic assumptions involving mergers of firms with more disparate market shares. We did not include these outliers in Figure 3.

95. This assumption seems reasonable and internally consistent; it means that a firm has no incentive to change its behavior if its demand and cost conditions and the prices it faces all remain unchanged. This assumption, called a "Nash equilibrium," is common in oligopoly model building. See, e.g., J. CASE, supra note 76, at 30.

96. Even if the nonmerging firms did not change their conjectures after a merger, the merging firms might change theirs and become more rivalrous. Ordover, Sykes, and Willig investigated this possibility in a paper examining the sensitivity of market power to changes in $k$. See Ordover, Sykes \& Willig, Herfindahl Concentration, Rivaly, and Mergers, 95 HARv. L. Rev. 1857 (1982). Analytically, they modeled an increase in rivalry as a decrcase in $k$. For example, under their model, if $k$ fell from $k=0$ to $k=-0.5$ and firms' costs remained unchanged, price would remain constant if 
This analysis demonstrates the difficulty of assessing the impact of a merger on market power. Without excellent information about all aspects of the relevant market model, including the psychological effects of a merger on other firms in the industry, we can say very little about the cost savings needed to offset market power effects. Even among the models that we discuss, the range of possible tradeoff values is very broad. In general, the less elastic the market demand in the relevant range, or the larger the market shares involved, the greater the cost savings must be to keep price from increasing and output from falling.

Nonetheless, our model building establishes a range of necessary efficiency gains sufficient to offset an increase in market power. Our simulations show that an above-Guideline merger in a noncollusive oligopoly, with a change in the HHI of up to 1,000 , would require decreases in marginal costs of 0 to $12.6 \%$ to keep price from increasing. The precise amount depends on the change im the HHI, the elasticity of demand, and the value of conjectural variations. If the merger changed the conjectures of nonmerging firms, the range would expand to include both negative and larger positive percentages.

These figures, however, do not represent "average" efficiency gains that merging firms would have to realize to keep price from rising. Rather, they cover a range of efficiency gains that might be necessary depending on how the merging firms viewed competition. While some mergers at the Guideline thresholds might not require any cost savings to prevent price rises, mergers significantly above the Guidelines might require substantial efficiency gains. Values at either the lower or upper end of the range are plausible if the underlying models are valid. Other models of conjectural variations could extend the range of possible requisite cost savimgs. Unfortunately, we have little theoretical or empirical basis to determine either the HHI levels or the non-structural conditions for which any given industry is likely to experience Cournot, collusive, or some other specific form of oligopolistic pricing behavior. ${ }^{97}$

Table 2 provides some perspective for the simulation results and helps demonstrate the relative importance of independent firm oligopoly

two equal-sized firms merged and would actually fall if firms of unequal size merged. Our models A$\mathrm{D}$ imply that $k$ either remains constant or increases (firms become more rivalrous) as a result of a merger.

Another approach would be to start with a dominant firm model. Mallela and Nahata, supra note 94, demonstrated that if a dominant firm acquired a fringe firm and transferred its lower costs to its acquired assets, price could increase, decrease, or remain constant. They showed that the greater the number of fringe firms, the greater the possibility that such an acquisition would lead to a decrease in price.

97. See, e.g., supra note 66; Pautler, supra note 60. A merger changes the underlying concentration (HHI). With the change in underlying structure, that is, increased concentration not exactly offset by efficiency gain, the firms are more able to collude. The incentive is unchanged; with additional concentration not offset by efficiency gains, the change is the increased ability to collude. 


\section{TABLE 2}

\section{Efficiency Gains Necessary to Prevent Price Increases*}

\begin{tabular}{|c|c|c|c|c|}
\hline & $\begin{array}{c}\text { (1) } \\
\text { Competition } \\
\text { to Cournot } \\
\mathrm{HHI}=2500 \dagger\end{array}$ & $\begin{array}{c}(2) \\
\text { Cournot } \\
\text { to Cournot } \\
\triangle \mathrm{HHI}=500\end{array}$ & $\begin{array}{c}\text { (3) } \\
\text { Cournot } \\
\text { to Monopoly } \\
\text { HHI }=2500 \dagger\end{array}$ & $\begin{array}{c}\text { (4) } \\
\text { Competition } \\
\text { to Monopoly } \downarrow \text {, }\end{array}$ \\
\hline $\begin{array}{l}=2 \\
=5 \\
=10\end{array}$ & $\begin{array}{c}12.5 \% \\
5.0 \\
2.5\end{array}$ & $\begin{array}{l}8.6 \% \\
3.3 \\
1.6\end{array}$ & $\begin{array}{l}42.9 \% \\
15.8 \\
7.7\end{array}$ & $\begin{array}{l}50.0 \% \\
20.0 \\
10.0\end{array}$ \\
\hline
\end{tabular}

Notes:

* For the formulas used to derive these figures, see Appendix A for column (2) and Appendix B for columns (1), (3), and (4).

For column (1), the postmerger HHI is 2500 ; for column (3), the premerger HHI is 2500. Since competitive, Cournot, and monopolistic pricing may occur over wide ranges of HHIs, one need not specify a change in the HHI for columns (1), (3), or (4). Also, column (2) applies for all HHI levels for which Cournot behavior applies.

The models in columns (1), (3), and (4) hypothesize extensive changes in market behavior from a single merger. See supra note 76, and infra notes 98 and 100. The model building in Appendix A, which underlies Figure 3, describes actual market behavior far more realistically.

For interpretation, see notes 95-105 and accompanying text.

$\dagger$ For columns (1), (3), and (4), the ealculations assume that all firms in the market-those merging and those not merging-achieve the same percentage reductions in marginal costs. One would normally expect only the merging firms to achieve the efficiency gains, as we assume in column (2). One might try to estimate the required cost savings in this case by dividing the cost savings in the table by the combined market share of the merging firms. For example, for competition to Cournot, $|\eta|=5$, and a combined market share of $40 \%$, one might expect the merging firms to need $12.5 \%$, not $5.0 \%$, cost savings to keep price from rising. However, with cost differences of $12.5 \%$ between the merging and other firms, there would not be a stable equilibrium. The merged firm would drive its competitors out of business unless they obtained comparable efficiency gains. Without more information, we could not predict the new equilibrium. However, we can say that the figures in columns (1), (3), and (4) understate the efficiency gains that would be necessary to keep price from increasing when only the merging firms obtain the cost savings.

$\ddagger$ Column (4) should equal column (1) plus column (3). Properly summed, it does. Take, for example, the second line. For competition to monopoly and $|\eta|=5$, marginal costs must fall by $20 \%$ to keep price from rising. In column (1), marginal costs fall by .05 , from 1 to .95 . Column (3) indicates that marginal costs must fall by a further .158 . A decrease of .158 means that marginal costs will be 1 minus .158 , or .842 of the Cournot level (which we found to be .95 from column (1)). From competition to monopoly, then, marginal costs will end up at (.842) (.95), or $80 \%$ of the competitive level-thus indicating a drop of $20 \%$. One can verify the other entries by following the same methodology. 
and collusion for the market power/efficiency tradeoff." The "theoretical maximum" decrease in marginal costs necessary to offset the increased market power and keep price constant would arise if a merger led an industry from competitive to monopolistic (perfectly collusive) pricing. The necessary reduction in inarginal costs is equal to $1 / \eta \eta,^{99}$ where $|\eta|$ is the elasticity of deinand evaluated at the coinpetitive price. Thus, under simphistic assuinptions, the "inaximum necessary" efficiency gains would be $10 \%$ for $|\eta|=10,20 \%$ for $|\eta|=5$, and $50 \%$ for $|\eta|=2 .{ }^{100}$ For a Cournot oligopoly and an HHI cliange of 500, the merging firms would need decreases in marginal costs of $1.6 \%, 3.3 \%$, or $8.6 \%$, depending on the elasticity of deinand. These efficiency gains are $16 \%$ to $17 \%$ of those necessary to offset tlie "theoretical nnaximum" increase in inarket power. ${ }^{101}$ With less anticompetitive conjectural variations (values of $k$ closer to -1 ), the necessary decreases in inarginal costs would be less than the amounts under Cournot assuinptions.

Alternatively, one might postulate that a inerger would transform an industry froin competitive to Cournot pricing. Under this assumption, the decrease in marginal costs necessary to keep price froin rising would range from $2.5 \%$ to $12.5 \%$ for a postmerger HHI of 2500 and

98. We undertake the comparisons in these two paragraphs and Table 2 with some reluctance, because it is generally unrealistic to assume that a single merger will transform any market from competitive to Cournot, from Cournot to monopolistic, or from competitive to monopolistic pricing. See supra note 66 and infra note 100 . Indeed, predictions of market transformations, all of which are probabilistic, are probably even more speculative than predictions of general market power and efficiency effects. The comparison, however, enables us to evaluate the relative importance of concentration (with independent pricing) and collusion.

99. For a graphical/algebraic proof in the special case of linear demand and constant marginal cost, see Fisher, Lande \& Vandaele, supra note 17. For a more general proof, see Appendix B, section $\mathbf{C}$.

100. If one interpreted the 1984 Merger Guidelines as defining a de minimis exception for price increases of up to $10 \%$, see supra note 48 , the cost savings necessary to offset a change from competitive to monopolistic pricing would be less. For example, the estimates of requisite cost savings reported in Fisher, Lande \& Vandaele, supra note 17, at 1704, would fall by 20 percentage points at each elasticity of demand, for a permitted price increase of $10 \%$.

These figures assume that the cost and price changes occur for the entire industry. If a merger created efficiency gains for only the merging firms, the required cost savings would be greater. However, one cannot generally say how much greater. If merger-specific efficiency gains brought a firm's marginal costs substantially below those of its competitors, the firms could be unable to agree on a common pricing scheme-collusion would be less likely, and one could not reliably predict price effects. With dramatic efficiency gains from a merger, one might expect dominant-firm pricing and a strong push among the remaining firms to duplicate the efficiency gains. The immediate postmerger results would thus not represent an equilibrium.

Another caution in interpreting tliese figures arises from the Department's methodology of defining a relevant product market for antitrust purposes. If firms could raise prices by more than $10 \%$ in response to a merger, the Department should logically argue that the proposed market was too broad. For an explanation, see supra notes $85-88$ and accompanying text.

101. For a Cournot oligopoly and an HHI change of 1000 , the necessary efficiency gains would be $2.3 \%, 4.7 \%$, and $12.6 \%$, depending on the elasticity of demand-roughly $23 \%$ to $25 \%$ of the "theoretical maximum." 
from $3 \%$ to $15 \%$ for a postmerger $\mathrm{HHI}$ of 3000 , for $|\eta|$ of 10 to $2 .^{102}$ These figures for the necessary efficiency gains are $25 \%$ of the "theoretical maximum" for a postmerger HHI of 2500 and $30 \%$ for a postmerger HHI of 3000 .

Although the rigid models summarized in Table 2 are less realistic and reliable than the results in Figure 3, they validate the focus in the Merger Guidelines on collusion as the major anticompetitive threat of merger. As Table 2 indicates, the most dramatic anticompetitive effects result only when a merger enables an industry to engage in collusive conduct. A merger producing a change in the HHI of 500 (column (2)) requires at most only $16 \%$ to $17 \%$ of the "theoretical maximum" efficiency gains necessary to offset a change from competitive to monopolistic (perfectly collusive) pricing.

Figure 3 summarizes the large range of results possible under our "theoretically neutral" model. Not all these values, however, are equally probable, especially for HHI levels and changes near or below the Guidelines. Most mergers are unlikely to raise price or restrict output. ${ }^{103}$ The assumptions underlying our models further reduce the likelihood of mergers requiring cost savings near the upper limits of the tradeoff values. Our models explicitly assume no possibility of entry; and for values of $k$ approaching zero (where the requisite efficiency gains reach their maximums), they implicitly assume that fringe firms have little ability to expand. ${ }^{104}$ Moreover, entry barriers tend to be highest in narrowly defined markets, where firms inhabit narrow niches and compete somewhat indirectly with similar products. The availability of similar products, however, usually corresponds to relatively elastic demand, which limits the merged firm's ability to raise price. This analysis implies that for narrowly defined markets with numerous (though imperfect) substitutes and high entry barriers (a $k$ value near zero), cost savings significantly less than the theoretical maximum would prevent price from rising. Thus for mergers near or below the Guidelines, the requisite efficiency gains would typically be near the bottom of the estimated ranges. The Williamsonian tradeoff of decreased costs and increased allocative inefficiency ${ }^{105}$ has only become relevant in the last half dozen years as the

102. For the formula, see Appendix B, section A. Again, if we assume that only the merging firms achieve the efficiency gains, the required cost reductions would be greater but not generally predictable. See supra Table 2 n.†.

103. For the experience under Hart-Scott-Rodino filings, supra note 1, see supra text accompanying notes 61-62. Even under an economic efficiency standard, the first step would be to assess the probability of an increase in market power leading to an increase in price. The record on second requests under Hart-Scott-Rodino indicates that the enforcers have judged this probability to be minimal in more than $90 \%$ of reported mergers in recent years.

104. Dropping the assumption of no entry is equivalent to assuming $k=-1$ (that is, entry would frustrate any attempts of the merged firm to restrict output and raise prices).

105. See Williamson, supra note 5 , at $22-23,34$. 
agencies and courts have started evaluating above-Guideline mergers with the potential to create or enhance market power.

\section{V \\ POLICY CONSIDERATIONS: WORKABILITY AND IMPLEMENTATION}

The modeling and simulations in Part IV demonstrate that oligopoly complicates the tradeoff between efficiency and market power. The discussion raises two obvious questions: is a price standard as workable as an efficiency criterion; and under either a price or an econounic efficiency approach, how can antitrust enforcers and the courts best incorporate efficiency considerations?

\section{A. Workability Considerations}

\section{Price Versus Economic Efficiency}

Price is inore workable than economic efficiency as a merger standard because its inodeling is more straightforward. Under the price standard, one needs to describe the industry and identify the values of a few underlying parameters to determine how large cost savings would have to be to prevent price from rising or output froin falling. This task alone, however, probably exceeds the abilities of the litigation system. ${ }^{106}$

A model that incorporated an economic efficiency standard would be even more complex and require much more information to solve. Unlike our treatment, an efficiency-based model would require that one evaluate the potential efficiency gams froin a merger even after determining that the inerger would probably lead to an increase in price and a fall in output. This tradeoff analysis would require that one know the firm's marginal cost and marginal revenue schedules over the relevant output ranges ${ }^{107}$ in addition to all the information needed to analyze a merger under the price standard. ${ }^{108}$ Economic efficiency advocates generally recognize the administrative coinplexity of their standard and therefore propose a simplified operational approximation-an output rule that is

106. The requirement that one distinguish between the effects of claimed efficiency gains on fixed and variable costs complicates use of a price standard. The price standard requires a focus on efficiency gains most likely to reduce price-variable (marginal) cost savings. Experience in predatory pricing litigation has shown that it is often difficult in practice to distinguish between fixed and variable costs. See, e.g., Hurwitz \& Kovacic, Judicial Analysis of Predation: The Emerging Trends, 35 VAND. L. REv. 63, 77-83 (1982). Indeed, a focus on variable cost savings inight even induce a firm inefficiently to switch some of its costs froin fixed to variable to help meet an efficiency test.

107. See supra note 73 .

108. The price standard also has an empirical advantage. It is soinetimes possible to observe after the fact whether price rose and output fell. By contrast, the tradeoff under the econounic efficiency test-whether unarginal costs fell sufficiently to offset the adverse effects of reduced output-eludes hindsight as well as foresight. 
virtually identical to the price standard. ${ }^{109}$ Indeed, when the Reagan administration proposed legislative reform of the Clayton Act in 1986, it recommended using an explicit price standard to evaluate mergers. ${ }^{110}$

\section{Case-by-Case Versus Rule-Based Approaches}

Whether one tests mergers by a price or an economic efficiency standard, the enforcement options range along a spectruin from case-by-case evaluation under a rule of reason standard to a rigid adherence to formal rules. ${ }^{111}$ Virtually every approach starts with inerger guidelines based on market structure. From this coinmon start, a formal, rule-based approach incorporates efficiency gains by raising the permissible concentration levels and changes to account for average gains in efficiency. ${ }^{112}$ The case-by-case approach at the other end of the spectrum assunes that enforcement agencies and courts can "properly" evaluate the tradeoff between market power increases and efficiency gains in most cases, without unduly increasing admimistrative and uncertainty costs. In theory, society could capture enormous gains by selectively permitting socially desirable above-guideline mergers and attacking undesirable acquisitions that would pass guidelines that had been raised to accommodate average efficiency gains.

109. See, e.g., Easterbrook, The Limits of Antitrust, 63 TEX. L. REv. 1, 31-33 (1984) (proposing a series of filters in an attempt to ensure that only practices likely to result in reduced output or increased prices would be subject to the Rule of Reason); Posner, The Next Step in the Antitrust Treatment of Restricted Distribution: Per Se Legality, 48 U. CHI. L. REv. 6, 21 (1981) (proposing to make a restriction's effect on output a central feature of an assessment of whether it increases competition) [hereinafter Posner, The Next Step]; Posner, The Rule of Reason and the Economic Approach: Reflections on the Sylvania Decision, 45 U. Chi. L. Rev. 1, 16-17 (1977) (proposing to determine the permissibility of restrictions on distribution by measuring their effects on output) [heremafter Posner, Reflections]; see also supra note 11 (describing why the output and price standards are virtually identical).

110. The Merger Modernization Act of 1986 proposed changing section 7 of the Clayton Act from a ban on mergers "substantially [likely] to lessen competition, or to tend to create a monopoly," 15 U.S.C. $\S 18$ (1982), to a ban on mergers likely to "increase the ability to exercise market power," S. 2160 , 99th Cong., 2d Sess. $\$ 2$ (a) (1986). The proposed bill defined the ability to exercise market power as "the ability of one or more firms profitably to maintain prices above competitive levels for a significant period of time." Id. at $\S 2$ (d). The 1986 proposal was the most serious of the administration's several attempts to amend the Clayton Act to institutionalize an efficiency defense. See supra note 25; see also Judge Ginsburg's discussion of the 1986 proposal, supra note 24.

111. Intermediate policies try to limit the area of subjective evaluation. However, although one can frequently carve out useful exceptions to rules or presumptions, unstructured or unclear approaches frequently degenerate into full-blown investigations (rule of reason at its worst). See generally, e.g., Easterbrook, supra note 109; Posner, The Next Step, supra note 109, and Posner, Reflections, supra note 109.

112. By "average gains in efficiency" we mean the average decrease in marginal costs that mergers of a certain HHI level and change would generate. Of course, the best one could do would be to make a rough estimate of what this figure might be. In practice, one would raise the HHI thresholds somewhat to account for this presumed effect. The Merger Guidelines apparently adopted this approach. See supra note 23. 
A case-by-case approach, however, would probably prove unworkably complex under either a price or efficiency standard. If done correctly, case-by-case implementation under either standard would require economic analysis far beyond the abilities of the merging parties, the enforcers, or the courts. Decision makers would need to determine which model and what parameter values correctly described the affected market ${ }^{113}$ before they could calculate the decrease in marginal costs necessary to justify the merger. ${ }^{114}$ They would also need to assess the likelihood that the requisite cost savings would actually arise. ${ }^{115}$

Allowing for product lieterogeneity (quality and variety changes) complicates the analysis even more. The question then becomes: "How much of a decrease im costs would compensate for a given increase in market power and ensure that price (for a given level of quality and variety) not increase, if we also expected quality or variety to increase by $x$ percent (or decrease by $y$ percent)?"116 If quality or variety and either price or cost were to change in the same direction, one would need to ensure that the cliange in quality or variety sufficiently compensated for the change im price or cost. ${ }^{117}$

113. See supra notes $65-67$ and accompanying text for a discussion of some of the difficulties inherent in constructing accurate models of oligopolistic markets.

114. Indeed, in practice, it would ofteu be difficult to distinguish the precise difference in the requisite cost savings under one standard from that under the other. There is one safe generalization: for an cconomic efficiency standard, cost saviugs would only need to be sufficieut to offset the deadweight loss of allocative inefficiency. A price standard, however, would require efficiency gains large enough to prevent price increases. The efficiency gains required by a merger would therefore be smaller under the economic efficieucy than under the price standard.

115. Experts have tended to make grossly inaccurate predictions of both efficiency gains and inefficiency losses from mergers. See Fisher \& Lande, supra note 5, at 1619-24, and infra note 132.

116. The same unanswerable question could equally well arise under an economic efficiency standard. For example, in Figure 1 we might require that rectangle $C$ equal triangle $D$ rather than requiring that price not mcrease. If one simplified the analysis by combining quality and variety as one complex additive factor, one could use a three-dimensional diagram to visualize this tradeoff. If one considered quality and variety as separate factors, one could.work with a series of threedimensional diagrams, each holding constant one of the parameters at a pre-selected value. In practice, this task would be even more difficult than it sounds.

117. This statement applies equally for an cconomic efficiency or a price standard. Suppose one expected both price and quality to decrease. To justify a merger, one would need to demonstrate that margiual costs would be likely to decrease sufficiently to offset the decline in quality. Otherwise, higher costs (diseconomies) might result from the merger with a reduced price masking the deterioration in quality. In theory, careful hedonic testing (testing that measures changes in quality) could determine whether prices fell sufficiently to offset any quality deterioratiou. However, even if the quality changes had already occurred, parties in litigation would rarely agree on hedonic estimatiug methodology. Similar factual questions arise when both pricc and quality increase.

Predicted (and therefore unknown) changes in product quality or variety are even harder to evaluate. One would need to anticipate in advance whether a proposed merger's expected efficiency gaius and lower price would be sufficient to compensate for anticipated reductions in product quality or variety. This task is inherently less reliable than observing actual changes that have occurred. The task might be impossible and would certainly be impossible to resolve through litigation. Whoever had the burden of proof would almost ccrtainly lose. See Fisher \& Lande, supra note 5, at $1634-35$. 
The testing necessary to ineasure changes in quality and variety is enormously difficult in theory; in litigation, it would probably be inpossible. ${ }^{118}$ Yet under either a price or an efficiency standard, a court evaluating mergers case by case would have to measure quality and variety changes to determine whether to permit a contested merger. ${ }^{119}$ This approach would force the court to balance a confusing and complex combination of dissimilar factors. The Commission had a hint of this confusion and complexity the first time after the 1982 revision of merger policy that it considered efficiency gains explicitly in a merger opinion. ${ }^{120}$

- The coinplications extend beyond product heterogeneity. Even when a inerger increases efficiency, the adjustment can be stormy, and the inerged company's inarginal costs inay decline only after a lengthy period. ${ }^{121}$ Moreover, at least one of the firms might have achieved comparable efficiency gains through less anticoinpetitive means, such as a licensing arrangeinent, joint venture, or less anticompetitive inerger. ${ }^{122}$ Alternatively, a merger between inultiproduct firms with only partial horizontal overlaps could create manageinent or other synergies or produce benefits for other products. Distinguishing between the effects of

118. See supra note 117 .

119. One court included the prediction of higher quality as an additional reason to allow a merger of two hospitals. This court, however, believed that merger would have no anticompetitive effect: it felt that the acquisition would lower, not raise, prices. United States v. Carilion Health System, 1989-1 Trade Cas. (CCH) \68,451 (D. W. Va. 1989).

120. See In re American Medical International, Inc., 104 F.T.C. 1, 220 (1984). In that case, the respondents argued:

In addition to saving costs, consolidation is expected to improve the quality of medical services by aggregating at a single facility patient volume that is now divided between the two hospitals. Higher volumes enhance quality by making it economically feasible for a hospital to upgrade its equipment and to reeruit and train expert support personnel. Moreover, increased volume provides greater opportunities for physicians and staff to sharpen their skills. Mr. Derzon, who has been involved in the hospital field for twentyfive years, testified that the quality enhancements flowing from consolidation are of even greater significance than the cost savings.

Brief in Support of Respondents' Proposed Findings of Faet and Conclusions of Law at 74, In re American Medical International, Inc., 104 F.T.C. 1 (1984) (Doc. 9158) (citations omitted) (on file with the authors). Neither the Administrative Law Judge nor the Commission found the arguments convincing. See 104 F.T.C. at 148-55, 219-20.

121. See, e.g., Rose, Occidental's Purchase of Cities Service Does Little to Increase U.S. Oil Reserves, Wall St. J., Dec. 5, 1984, at 24, col. 1; Wells \& Hymowitz, Takeover Trauma: Gulf's Managers Find Merger Into Chevron Forces Many Changes, Wall St. J., Dec. 5, 1984, at 1, col. 6; Magnet, Acquiring Without Smothering, ForTune, Nov. 12, 1984, at 22. In some cases, a merger may appear in retrospect to have been a great success for a while but then ultimately to have been a mistake - or vice-versa. For an example, see infra note 132.

122. For some discussion of how members of the Commission's staff have been evaluating these and other issues in practice, see R. Stoner, Merger Enforcement at the FTC Under the New Merger Guidelines (July 2, 1985) (unpublished manuscript) (presented at the Western Economic Association Meetings, Anaheim, Cal., July 2, 1985) (on file with the authors); C. Pidano \& L. Silvia, Analysis of Efficiencies in Horizontal Mergers and Joint Ventures at the FTC's Bureau of Economics (Nov. 1984) (unpublished manuscript) (presented at the Southern Economic Association Convention, Atlanta, Ga., Nov. 1984) (on fle with the authors). 
claimed efficiency gaims on fixed and variable costs complicates the analysis even more. ${ }^{123}$ These and other considerations ${ }^{124}$ clearly imply that the tradeoff calculations would typically be horribly complex in practice, especially given the creativity of antitrust attorneys and economists.

During litigation, each side would have experts with very different opinions of the appropriate inodel and values of the paraineters. Each side would try to convince or confuse a judge whose training and experience would typically be neither in economics nor in business. ${ }^{125}$ The legal system is far better suited to resolving "either-or" disputes than to balancing factors in a nultivariable analysis, especially under the tine constraints of a prelimimary injunction setting. ${ }^{126}$

\section{B. Enforcement Options}

Perhaps because they recognize the difficulties of a case-by-case approach, neither the courts nor the enforcement agencies, seein to attenipt this complex tradeoff very often. Based on the authors' collective experience in the area, the typical merger analysis assumes away the problem: it finds either anticompetitive effects probable and efficiency gams inplausible, or anticompetitive effects unlikely and merger-specific efficiency gains convincing. Many decisionmakers may avoid recognizing the tradeoff because there has not yet been a satisfactory way to assess how extensively efficiency nust increase to offset nuarket power effects in oligopolistic inarkets where the tradeoff is most hikely to be relevant. ${ }^{127}$ Moreover, a decisionniaker might nistrust her ability to calculate these gains and costs even if she knew the target values. Suppose a specific nerger would need to generate $3.3 \%$ marginal cost savings to offset probable market power effects. Who would wish to predict that a given inerger would be likely to generate only $3.1 \%$ marginal cost savings rather than the required $3.3 \%$ ? $^{128}$

123. The price standard requires a focus on efficiency gains most likely to reduce pricevariable (marginal) cost savings. It is often difficult in practice to distinguish fixed from variable costs. See supra note 106.

124. For an extensive discussion of these complicating considerations, see Fisher \& Lande, supra note 5 , at $1624-50$.

125. For a thorough exposition, see id. at 1651-77.

126. See Henderson, Judicial Review of Manufacturers' Conscious Design Choices: The Limits of Adjudication, 73 COLUM. L. REV. 1531, 1534-42 (1973) (discussing the notion of "polycentric" decisionmaking in the design defect context). Professor Henderson drew this concept from Fuller, Adjudication and the Rule of Law, 1960 Proc. AM. Soc'y INT'L L. 1, and M. Polanyi, The Logic OF LIBERTY 170-84 (1951).

127. The tradition of denying a tradeoff has a clear precedent in the congressional debates over the antimerger statutes. See supra text accompanying notes 31-39.

128. Officials using an economic efficiency standard might have another reason to ignore the existence of a tradeoff. They might be unwilling to admit that they decided against challenging a merger even though they expected it to lead to higher prices for consumers. 
Because of its greater complexity, a case-by-case approach is more expensive than a rule-based one. Litigation of a complex rule of reason case can cost millions of dollars and take years, especially with appeals, to establish the ultimate legahty of a transaction. Uncertainty over the legal status of a merger also raises other costs. Any firm whose merger was challenged would have to allow for the possibility of a forced divestiture. This possibility makes planming more expensive. Uncertainty over the legality of a class of potential mergers makes long-term planning more costly for all firms, both those considering acquisitions and those anticipatimg having to react to others' mergers. ${ }^{129}$ The intractability of the tradeoff for hitigation has led most leading antitrust scholars to argue against even attempting to balance market power and efficiency in individual mergers. ${ }^{130}$ In short, the costs associated with merger litigation and the uncertainty it produces would be likely to exceed any expected benefits of case-by-case analysis. ${ }^{131}$

129. Merger policy analysis generally focuses on two types of error that the enforcement agencies and courts may make. They may prevent beneficial mergers (Type 1 error) or permit undesirable mergers (Type 2 error). We have previously introduced the terminology of Type 3 error to summarize the generally overlooked administrative, planning, litigation, and other hidden costs of overly subjective and unpredictable antitrust enforcement. See Fisher \& Lande, supra note 5, at 1670-77. For a formal analysis, see Fisher \& Sciacca, supra note 60, at 72-75. Indeed, a prominent attorney who regularly handles Hart-Scott-Rodino filings confessed to one of the authors that his clients sometimes propose questionable mergers with the intention of abandoning the effort if the antitrust enforcers issue a second request or pose serious concerns. For some relatively small transactions, the projected gains (given the purchase price) are less than the cost of complying with a second request. Even for larger transactions, the expected gains may not outweigh the out-of-pocket and uncertainty costs of the litigative process.

130. See Fisher \& Lande, supra note 5, at 1651-59, for discussion and citations to Bork, Posner, Easterbrook, and other scholars. The major exceptions are Areeda and Turner, who would make the conditions so strict that virtually no merger could qualify, P. AREEDA \& D. TURNER, supra note 5, at If 939-962, and the Reagan administration's policy of considering anticipated efficiency gains in every close merger decision, see, e.g., 1984 Merger Guidelines, supra note 23, at $\$ 3.5$.

In United States v. Philadelphia National Bank, 347 U.S. 321, 371 (1963), the most recent Supreme Court decision to address the tradeoff explicitly in a merger context-admittedly now old - the Court's conclusion is consistent with our view. The Court concluded that balancing "economic debits and credits ... [was] beyond the ordinary limits of judicial competence...." See also United States v. Rice Growers Ass'n of California, 1986-2 Trade Cas. (CCH) \ 67.287, at 61,467 (rejecting a motivation to modernize at the lowest possible cost as a defense for an otherwise anticompetitive merger). For a more thorough discussion of the ability of courts to assess efficiency effects, see Fisher \& Lande, supra, at 1656-59; see also Bork, supra note 7 (discussing the difficulties that arise when courts attempt case-by-case economic analysis of mergers). For extensive citations and a discussion of problems with the rule of reason approach in the related context of nonprice vertical restrains, see Easterbrook, Vertical Arrangements and the Rule of Reason, 53 ANTITRUsT L.J. 135, 153-57 (1984).

131. Any logical rule would permit mergers whose net benefit under the legislative criteria would probably be positive and disallow cases whose net social benefit would probably be negative. Remaining cases would tend to be those about which reasonable experts would disagree and/or cases whose expected net social benefit would be close to zero. For a detailed analysis, see Fisher \& Lande, supra note 5, at 1651-77; for a formalization, see Fisher \& Sciacea, supra note 60, at 72-75.

Judge (then Professor) Easterbrook expressed a similar sentiment in recommending a simple screen based on output changes for evaluating the legality of vertical restraints: "F. M. Scherer's 


\section{Recent Enforcement Approaches in Light of Our Findings}

Although price is more workable than economic efficiency as a merger standard, we believe that enforcers would be unable to handle either rehably on a case-by-case basis. The enforcement system, however, can incorporate the required efficiency gains imphicitly, on average, rather than in individual cases. Of course, one could nake exceptions in rare cases if truly significant merger-specific efficiency gains seeined virtually certain. However, as the 1982 Merger Guidelines recognized, one should apply the exceptions cautiously. ${ }^{132}$

When the Department revised its enforcement approach for mergers in the early 1980s, it recognized that a case-by-case efficiency defense would be a hitigation inghtmare. The Department did not, however, have any basis to challenge the arguments of those who argued that decreases

demonstration that the output test could be inaccurate in some cases does not affect the point. If these cases are sufficiently rare, as his own analysis suggests they will be, then the output filter still has value. We are searching for useful filters, not perfect ones." Easterbrook, supra note 109, at 31 n.64 (citation omitted).

132. For example, LTV Corp.'s 1984 acquisition of Republic Steel seemed to offer clear efficiency potential, particularly since LTV had previously obtained significant cost reductions from its 1978 acquisition of Lykes Corporation's Youngstown Steel. See, e.g., Loomis, U.S. Steel and LTV Find Hidden Charms in Losers, ForTUNE, Mar. 5, 1984, at 118, which states that the Lykes acquisition lowered LTV's average cost of making steel by about $\$ 15$ a ton and predicts similar results from the Republic acquisition. Indeed, Assistant Attorney General for Antitrust J. Paul McGrath approved the acquisition, overruling his staff's recommendation, in part because of anticipated efficiency gains:

[I] $n$ the LTV-Republic merger, there was very persuasive evidence that the combined operation of several plants could have, and indeed should have, and probably would have resulted in substantial cost savings. ... [W] certainly did conciude, at lcast as to that one part of the efficiency claim, that the evidence was very clear, very convincing, and certainly up to anyone's standards.

McGrath Statement, supra note 3, at 141-42.

The Republic acquisition, however, turned out to be "Disasterville," with customer desertion, computer snafus, poor employee morale, and major underestimates of the time required to consolidate operations sufficiently to reduce operating costs. See, e.g., Why LTV Is Stymied in Steel, Bus. Wk. 65, Apr. 1985, at 65; O'Boyle \& Russell, Troubled Marriage: Steel Giants' Merger Brings Big Headaches, J\&L and Republic Find, Wall St. J., Nov. 30, 1984, at 1, col. 6. Largely because of the merger, LTV filed for proteetion under Chapter 11 of the Bankruptcy code on July 17, 1986. Beazley \& Russel, LTV Chapter 11 Filing Will Change the Way Steel Mills Compete, Wall St. J., July 18 , 1986, at 1, col. 6 .

Although LTV eventually achieved cost savings from the merger, these benefits apparently represented wealth transfers rather than true efficiency gains. Indeed, under bankruptcy protection, LTV was able to transform itself into the "most efficient of the nation's major steelmakers." Chapter 11's Safe Harbor Has Its Shoals, Wall St. J., Apr. 15, 1987, at 2, col. 2. It shifted "massive unfunded pension liabilities" to the federal Pension Benefit Guaranty Corp., thereby making that agency insolvent. It also escaped from long-term contracts that had foreed it to accept iron ore and coal at prices well above market levels. These cost reductions enabled LTV to reduce its pre-tax cost of making and shipping steel from around $\$ 460$ to $\$ 380$ a ton and to become the lowest cost major U.S. steel manufacturer. Id. The Supreme Court has agreed to decide whether the Pension Benefit Guaranty Corp. may require that LTV Corp. reassume funding responsibility for the $\$ 2.3$ billion shortfall in its pension plans. Wermiel, High Court to Rule on Whether LTV Should Fund \$2.3 Billion Pension Gap, Wall St. J., Oct. 31, 1989, at A3, col. 2. 
in marginal costs of as little as $1 \%$ to $2 \%$ would offset virtually all the adverse effects of anticompetitive mergers. ${ }^{133}$ Our model building provides this evidence. We demonstrate that in the relevant context of noncollusive oligopoly, the decrease in marginal costs necessary to keep price from rismg is probably far greater than previous autliors had believed. Efficiency gains of 0 to $9 \%$ would be required to ensure that mergers of the size that the enforcement agencies routinely evaluate would not lead to higlier prices.

These calculations, however, depend critically on the probability of collusion. The price-increasing effects of collusion are far more significant than the effects of imcreased concentration among independently operating oligopohists. When a merger makes collusion significantly more likely, the required cost reductions could increase substantially, perhaps to several times as much, to levels far in excess of the efficiency gains that one could realistically anticipate from a merger.

Our specific results assume the price standard. With economic efficiency as the criterion, the required decreases in marginal costs would be smaller. Because the economic efficiency standard is vastly more complex to model, we cannot directly compare our results to those that an efficiency standard could imply. However, guidelines relying on a price standard would by definition permit fewer mergers than guidelines relying on an efficiency test. ${ }^{134}$

To the extent that the government used economic efficiency as the sole basis for the HHI standards in the Merger Guidelines-or for whatever standards it currently follows ${ }^{135}$-the thresholds are too high. Ideal merger guidelines would use a price standard and incorporate the average effects of mergers on marginal costs and the probability of anticompetitive behavior as a result of increased concentration. They

133. Our finding of much larger required efficiency gains represents a combination of our using price rather than economic efficiency as a merger standard, our constructing explicit oligopoly models rather than using a more ad hoc approach, and our having access to actual data on HHI levels and changes for mergers that firms are actually proposing. For the arguments that efficiency gains of $1 \%$ to $2 \%$ would be sufficient, see supra notes 5 and 43 .

134. The price standard permits mergers unlikely to result in higher prices. An economic efficiency standard would permit the same mergers and also allow mergers likely to lead to higher prices, as long as the mergers were substantially likely to generate sufficient efficiency gains. For a diagrammatic explanation of the differencc between the two standards, see supra Figure 1 and accompanying text.

135. Enforcement standards during the last few years of the Reagan Administration were more lenient than those in the Merger Guidelines. See, e.g., Krattenmaker \& Pitofsky, Antitrust Merger Policy and the Reagan Administration, 33 ANTITRUST BuLl. 211, 226-32 (1988). The authors conclude that there has been a "[d] facto doubling of the HHI standards . . . ." Id. at 228. See also Conference Board Seminar, supra note 23 (discussing Ira Millstein's view that the Reagan administration used secret merger guidelines), and supra note 80 (demonstrating that HHI levels and changes in challenged cases have been substantially above the Merger Guideline thresholds). 
would also reflect Congress' desire to interdict anticompetitive developments in their incipiency. ${ }^{136}$

The National Association of Attorneys General (NAAG) treats efficiency gains most consistently with the results of our modeling. The NAAG considers increases in efficiency only for inergers of inodest size in moderately concentrated markets with postmerger HHIs less than $1800 .^{137}$ Our sinulation results suggest that any inarket power effects of mergers near the Guideline trigger (a postmerger HHI level of 1800 and an increase of 100) usually require only inodest efficiency gains to keep price froin rising (especially if collusion would not be a major threat at these HHI levels). In contrast, mergers that result in much higher HHI levels or larger changes often require extensive savings in marginal costs-frequently much larger than one could expect from any inerger, and certainly larger than one could predict reliably in advance.

The Departinent of Justice and the Federal Trade Commission, however, still doininate inerger enforcement, and they have shifted in recent years from a rule-oriented to a more subjective, rule of reason approach, ${ }^{138}$ based primarily on an efficiency rather than a price standard. ${ }^{139}$ Defendants' attorneys now routinely present the government with efficiency arguments designed to justify mergers that they would not have proposed before the inid-1980s. ${ }^{140}$ The governinent has permitted soine mergers at levels significantly above the Guideline thresholds, in whole or in part because of anticipated efficiency gains. ${ }^{141}$ However, neither the Departinent nor the Coininission has specified by how much a merger must be likely to reduce marginal costs to offset a presuinption of illegality.

136. Since these factors go beyond the scope of our paper, we do not suggest how ideal HHI standards would differ from the levels in the Merger Guidelines or any implicit standards that the enforcement agencies may now be using.

137. See supra note 26 and accompanying text. Moreover, because the NAAG Guidelines incorporate wealth transfer concerns, they are logically somewhat stricter than the federal standards. We do not address the workability of the NAAG Guidelines.

138. The courts have also been moving toward rule of reason in other aspects of antitrust, such as vertical restraints and horizontal restraints. See, e.g., Gellhorn \& Tatham, Making Sense Out of the Rule of Reason, 35 CASE W. RES. L. REv. 155 (1985) (giving examples where per se standards have given way to rule of reason or other types of more involved analysis).

139. However, in practice the administration may sometimes use or advocate a price standard. See, e.g., supra notes 3, 50-51; supra note 110 and accompanying text.

140. For example, in In re American Medical Int'l, Inc., 104 F.T.C. 1 (1984), the Commission discussed two possible geographic market definitions and two different units of measurements. The acquiring firm's market share was between 52.2 and $57.8 \%$; the acquired firm's share, between 19.1 and $29.2 \%$. The postmerger HHI was between 5507 and 7775, and the change was between 1989 and 3405. Id. at 201. Compare Table 1 and text accompanying supra notes 79-80 with 1984 Merger Guidelines, supra note 23 , at $\S 3.11 ; 1982$ Merger Guidelines, supra note 21 , at $\S$ III.A.1.

141. See supra note 132 and Table 1. 
The myriad of complexities in each proposed merger makes it unlikely that courts or agencies could balance efficiency against market power accurately in individual cases. At least in theory, researchers could examine past above-Guideline mergers to evaluate whether the predicted cost savings and quality enhancements have indeed arisen and compensated for allocative efficiency or price effects. But even if research were able to show that the courts and agencies were performing the balancing correctly in a majority of cases, the case-by-case approach of recent years is probably creating enormous uncertainty costs for businesses. Estimatimg the impact of the subjective rule of reason approach on business planning and transaction costs would be far more difficult than evaluating whether the courts and agencies have been performing the balancing correctly. We expect, however, that case-by-case balancing would not generate enough net gain to outweigh the costs of an overly subjective enforcement pohicy. ${ }^{142}$ For that reason, we believe that it would be more effective to incorporate anticipated efficiency gains directly, but imphicitly, into the merger standards.

142. To use our terminology, see supra note 129 , we believe that Type 3 error costs would exceed any net gains in the sum of Types 1 and 2 error. For an example of the difficulty in avoiding Types 1 and 2 error in individual mergers, see supra note 132. 


\section{APPENDIX A}

\section{A "Theoretically NeUtral" Approach FOR EVALUATING THE TRADEOFF}

The model building in this Appendix underlies the material in section IV.C. We use assumptions and models as general as possible to address the question of how much a merger must reduce marginal costs to offset the market power inherent in a merger in an oligopoly comprised of noncolluding firms. ${ }^{143}$

Assume that a firm chooses a level of output $\left(x^{*}\right)$ such that marginal revenue (MR) equals marginal cost (MC) at that output. Conceptually, with no change in industry demand, an increase in market power for a firm implies a downward shift in the firm's MR curve. All else equal, the new intersection of the MR and MC curves would lie to the left of the initial intersection and imply a lower level of output and, consequently, a higher price to consumers. To calculate the new output, one would have to know the shapes of both the MC and the new MR curves over their relevant ranges - a formidable informational requirement.

Fortunately, our characterization of the problem minimizes the information necessary to determine the effects of a merger. We want to know how great efficiency gains would have to be to offset any price effects of a merger. Equivalently, how much would the $\mathrm{MC}$ curve have to shift down to intersect the new MR curve at the initial output level $x *$ ? This formulation narrows our focus. We need compare equilibrium conditions only at output $x^{*}$; we do not need to know anything about the rest of the MR or MC curves. Our results therefore generalize over all possible combinations of MC and MR curves whose intersection at $x *$ is consistent with profit maximization.

Nevertheless, one large informational problem remains. How does a firm perceive its $M R$, and how does this perception change with a merger? To answer this question, we assume a market of $\mathrm{n}$ firms producing a homogeneous product, and no prospect of new entry. ${ }^{144}$ Marginal revenue for a typical firm is:

143. One might use "model" for two distinct meanings relevant to this Appendix: the nature of firms" conjectures and the way their conjectures change in response to a merger. To avoid this potential confusion, we use "assumptions" when discussing the first meaning and "model" when discussing the second. We also use "model building" to describe the entire process of developing integrated models and assumptions to describe a market.

144. When entry is quick and easy, the market will eliminate any antitrust problems. In words that should be immortal, Senator Sherman, who introduced the Sherman Act, stated: "[I]f other corporations can be formed on equal terms a monopoly is impossible." 21 CoNG. REC. 2457 (1890). 
(1)

$$
\mathrm{MR}_{\mathrm{i}}=\mathbf{P}\left[1+\frac{s_{\mathrm{i}}}{\eta}\left(1+k_{\mathrm{i}}\right)\right] \text {, where }
$$

$\mathbf{P}$

is price,

$s_{\mathrm{i}}$

is firm $i$ 's market share, $0<s_{\mathrm{i}}<1$,

$\eta$

is the industry's price elasticity of demand, $(\eta<0)$, and

$k_{\mathrm{i}} \quad$ is firm $i$ 's conjectural variation, ${ }^{145}$ where

$$
k_{\mathrm{i}}=\sum_{j \neq i} \frac{\partial \mathrm{x}_{j}}{\partial x_{i}}
$$

That is, firm $i$ 's conjectural variation is the sum of the changes in output by all other firms (each firm $i$ such that $j$ is different from $i$ ) for a given change in firm $i$ 's output.

Suppose that firms 1 and 2 merge. Their new MR becomes:

(2) $\mathrm{MR}^{\prime}=\mathrm{P}\left[1+\frac{s_{1}+s_{2}}{\eta}\left(1+k^{\prime}\right)\right]$,

where $k^{\prime}$ is the merged firm's conjectural variation.

The parameters in equations (1) and (2) are fairly straightforward to estimate, with the exception of the conjectural variations $k$ and $k^{\prime}$. There is no general consensus in the literature on the numerical values of conjectural variations in oligopolistic situations, although economists frequently use two rather extreme values for computational simplicity. Cournot assumptions are that the merged firm anticipates no output response from its competitors $(k=0) .{ }^{146}$ Competitive assumptions are the

145. To simplify the presentation, we treat $k$, as a constant. More generally, $k_{\text {, may vary with }}$ $x_{1}$. For our analysis, it is immaterial whether $k_{1}$ be a constant or a function of output, because we examine changes in MR at a single level of output, not over a range of outputs.

146. Salant, Switzer, \& Reynolds, Losses from Horizontal Merger: The Effects of an Exogenous Change in Industry Structure on Cournot-Nash Equilibrium, 98 Q.J. EcoN. 185 (1983), demonstrate that in a Cournot model with constant MC, no two firms would have an incentive to merge as long as there were three or more price-searching firms in the industry. Intuitively, in that situation the gains from the increase in market power would all go to the nonmerging firms. These results raise the question of the legitimacy of a Cournot model for simulating merger behavior. Perry \& Porter, 
opposite, that the merged firm anticipates complete and exactly offsetting output responses $(k=-1)$. Except under competitive conditions, firms in otherwise similar circumstances would normally be unlikely to have similar conjectural variations, since these parameters are primarily subjective phenomena (surmises). Hence, it would be unrealistic to argue for any particular value of $k$ as a general case. Instead, we examine conjectural variations over the entire range from competitive to Cournot $(-1$ $\leq k \leq 0$ ) and report the range of outcomes.

We must still model how firms change their conjectural variations (from $k$ to $k^{\prime}$ ) when they merge. There are two parts to this question. First, how do the merging firms' perceptions of $k$ change? Second, how do the remaining firms in the industry alter their own perceptions? We assume that the remaining firms do not change their actions or perceptions as long as the merging firms do not alter their combined output. This assumption is consistent with the initial vector of industry outputs being a Nash equilibrium. ${ }^{147}$

We consider four separate models of how $k$ for the merging firms changes after the merger. In each of these models, $0 \geq k^{\prime} \geq k$.

Model A: $k^{\prime}=k_{1}$. The simplest model is that $k$ does not change at all.

Model B: $\quad k^{\prime}=k_{1}\left(1-s_{1}-s_{2}\right) /\left(1-s_{1}\right)$. This relationship follows from a model in which a firm's conjectural variations are proportional to the percentage of the market that it does not control.

(i) $k_{1}=\alpha\left(1-s_{1}\right)$;

(ii) $k^{\prime}=\alpha\left(1-s_{1}-s_{2}\right)$ $=k_{1}\left(1-s_{1}-s_{2}\right) /\left(1-s_{1}\right)$

Model C: $\quad k^{\prime}=k_{1}\left(\mathrm{HHI}-s_{1}{ }^{2}-s_{2}{ }^{2}\right) /\left(1-s_{1}{ }^{2}\right)$. This model is similar to Model $\mathrm{B}$, except here $k$ is proportional to the sum of squared shares of the other firms in the market.

Model D: $\quad k^{\prime}=k(n-2) /(n-1)$, where $n$ is the number of firms in the industry before the merger. In this model, the firms' shares do not matter. Instead, $k$ changes as the number of firms changes.

Oligopoly and the Incentive for Horizontal Merger, 75 AM. ECON. REv. 219 (1985), relax the assumption of coustant MC and show that merger can be profitable in a Cournot model with more than two firms. Our simulations make no assumptions about the shape of the MC curves because our concern is only with how much MC would have to decline at a specified output level.

147. See supra note 95 . 
For any given model and initial value for $k$, we can compare the bracketed terms in equations (1) and (2) for each of the merging firms and calculate the percentage decrease in each firm's MR at its initial output level. ${ }^{148}$

$$
\begin{aligned}
\% \Delta \mathrm{MR}_{i} & =100\left[\left(\mathrm{MR}^{\prime}-\mathrm{MR}_{i}\right) / \mathrm{MR}_{i}\right] \\
& =100 \frac{\left(s_{1}+s_{2}\right)\left(1+k^{\prime}\right)-s_{i}\left(1+k_{\mathrm{i}}\right)}{\eta+s_{\mathrm{i}}\left(1+k_{i}\right)}
\end{aligned}
$$

If their MC's decrease by the same percentage, the merging firms will mamtain their initial levels of production. Therefore, equation (3) also determines the magnitude of efficiency gains necessary to offset exactly the price effects of a merger.

Equation (3) demonstrates that the percentage decrease in marginal costs necessary to keep output from falling (price from increasing) depends on conjectural variations (the specific oligopoly model), the market shares of the merging firms, and the elasticity of demand. The shares of the merging firms directly translate into the change in the HHI, which equals $2\left(100 s_{1}\right)\left(100 s_{2}\right)$.

148. MR always decreases as a result of a merger when $k^{\prime} \geq k$ and may decrease when $k^{\prime}<k$. A decline in MR implies that the term \% $4 \mathrm{MR}$ in equation (3) is negative. The denominator is negative whenever $M R$ is positive (see equation (1)), as would clearly be true at the profitmaximizing level of output $x^{*}$, given positive MC. Similarly, the numerator is positive, since

$$
\begin{gathered}
\qquad\left(s_{1}+s_{2}\right) / s_{i}>1 \text { for } i=1,2, \text { and } \\
1 \geq\left(1+k_{i}\right) /\left(1+k^{\prime}\right), \\
\text { since } k^{\prime} \geq k_{i} \text {. Hence, } \mathrm{MR}<0 .
\end{gathered}
$$




\section{APPENDIX B}

\section{Tradeoffs for Market Structure Changes: COMPETITION TO OLIGOPOLY AND OLIGOPOLY TO MONOPOLY}

In this Appendix, we derive the decreases in marginal costs necessary to keep prices from rising under three scenarios: competitive to Cournot, Cournot to monopolistic, and competitive to monopolistic. These proofs underlie the calculations in sections IV.C and IV.D. The most convenient assumption is that both cost and price changes occur for the entire industry. If we assumed instead that the efficiency gains accrued only for the merging firms and the price rises occurred for all firms, the required decreases in marginal costs would be greater. However, because this scenario implies significant cost differences among firms in the same market, the situation would not represent a stable equilibrium. ${ }^{149}$

Once we have determined the decreases in marginal costs necessary to keep prices from increasing, we can use that information to derive the critical elasticities of demand for which price would increase by exactly $x$ percent if the firms colluded. Details of the proof depend on the exact specification of the demand function. We illustrate the process with a proof for constant elasticity of demand and Cournot assumptions, the least complex to analyze formally. ${ }^{150}$

The following definitions for subscripts facilitate the proofs:

s starting condition

e ending condition

1 competitive

2 Cournot

3 monopolistic

149. See the caveats supra note 100 and Table 2 , note $f$.

150. This proof underlies the calculations for supra note 89 and the accompanying text. 
We also define the following terms:

P price

MC marginal cost

$\mathrm{Q} \quad$ industry output

$f, g$ functions of

$\alpha \quad$ proportionate change in price, $0 \leq \alpha \leq 1$

$100 \alpha \quad$ percentage change in price

$|\eta| \quad$ absolute value of the elasticity of demand

hhi HHI/10,000 (thus transformed to decimal)

$\mathrm{R}$ percentage change in $\mathrm{MC}$ required to keep $\mathrm{P}$ from increasing; $\mathrm{R}=\left(\mathrm{MC}_{\mathrm{e}} / \mathrm{MC}_{\mathrm{s}}\right)-1$

Firms maximize profits by selecting output where marginal cost equals marginal revenue. Different market structures generate changes in the relationship between price and marginal revenue, and thus the relationship between marginal cost and price. The following relationships are well known from economic theory:

$$
\mathrm{MC}_{1}=\mathrm{P}_{1} \text {, or }
$$$$
\mathrm{P}_{1}=\mathrm{MC}_{1} \text { for competitive pricing. }
$$

$\left(\mathrm{P}_{2}-\mathrm{MC}_{2}\right) / \mathrm{P}_{2}=\mathrm{hhi} /|\eta|$, or

$\mathrm{P}_{2}=\mathrm{MC}_{2} /(1-\mathrm{hhi} /|\eta|)$ for Cournot pricing.

$\mathrm{MC}_{3}=\mathrm{P}_{3}(1-1 /|\eta|)$, or

$\mathrm{P}_{3}=\mathrm{MC}_{3} /(1-1 /|\eta|)$ for monopolistic pricing.

We define:

$$
\begin{aligned}
& P_{s}=f\left(M C_{s}\right) \\
& P_{c}=g\left(M C_{e}\right) .
\end{aligned}
$$

Suppose that a merger changes the market structure and leads to a price increase from $P_{s}$ to $P_{e}$. Since we defined $\alpha$ as the proportionate increase in price (for example, if price increased by $10 \%$ then $\alpha$ would equal 0.10 ), then

$$
\mathrm{P}_{\mathrm{e}} / \mathrm{P}_{\mathrm{s}}=1+\alpha .
$$


Since we can write price as a function of marginal cost (see equations $\left(1^{\prime}\right)$ through $\left(3^{\prime}\right)$ ), we can substitute these equations into equation (6) to obtain the proportionate change in marginal cost that corresponds to the $\alpha$ increase in price.

\section{A. Competitive to Cournot}

Suppose that a market goes from competitive to Cournot. Substituting $\left(2^{\prime}\right)$ and $\left(1^{\prime}\right)$ into (6) yields:

$$
\frac{\mathrm{MC}_{2} /(1-\mathrm{hhi} /|\eta|)}{\mathrm{MC}_{1}}=1+\alpha \text {, or }
$$

$$
\mathbf{R}=\left(\mathrm{MC}_{2} / \mathrm{MC}_{1}\right)-1=(1+\alpha)(1-\mathrm{hhi} /|\eta|)-1,
$$

which shows the proportionate change in $\mathrm{MC}$ necessary to make $\mathrm{P}$ change by $\alpha$. To keep price constant, we solve for $\alpha=0$ :

$$
R=-h h i / \eta \mid \text {, for competitive to Cournot. }
$$

\section{B. Cournot to Monopolistic}

Suppose a market goes from Cournot to monopolistic pricing. Substituting $\left(3^{\prime}\right)$ and $\left(2^{\prime}\right)$ into $(6)$ yields:

$$
\begin{aligned}
& \frac{\mathrm{MC}_{3} /(1-1 /|\eta|)}{\mathrm{MC}_{2} /(1-\mathrm{hhi} /|\eta|)}=1+\alpha, \text { or } \\
& \mathrm{R}=\left(\mathrm{MC}_{3} / \mathrm{MC}_{2}\right)-1 \\
& =(1+\alpha)[(|\eta|-1) /(|\eta|-\text { hhi })]-1,
\end{aligned}
$$

which shows the proportionate change in $\mathrm{MC}$ necessary to make $\mathrm{P}$ change by $\alpha$. To keep price constant, we solve for $\alpha=0$ :

$$
\begin{aligned}
& \mathrm{R}=[(|\eta|-1) /(|\eta|-\mathrm{hhi})]-1 \text {, or } \\
& \mathrm{R}=(\text { hhi }-1) /(|\eta|-\text { hhi }), \text { for Cournot to } \\
& \text { monopolistic. }
\end{aligned}
$$




\section{Competitive to Monopolistic}

Suppose that a merger transforms an industry from competitive to monopolistic pricing and also lowers the marginal costs of the remaining firm(s). Substituting $\left(3^{\prime}\right)$ and $\left(1^{\prime}\right)$ into (6) yields:

$$
\begin{aligned}
& \frac{\mathrm{MC}_{3} /(1-1 /|\eta|)}{\mathrm{MC}_{1}}=1+\alpha, \text { or } \\
& \mathrm{R}=\left(\mathrm{MC}_{3} / \mathrm{MC}_{1}\right)-1=(1+\alpha)(1-1 /|\eta|)-1,
\end{aligned}
$$

which shows the proportionate change in $\mathrm{MC}$ necessary to make $\mathrm{P}$ change by $\alpha$. To keep price constant, we solve for $\alpha=0$ :

$$
\begin{aligned}
& \mathrm{R}=\left(\mathrm{MC}_{3}-\mathrm{MC}_{1}\right) / \mathrm{MC}_{1} \doteq-1 /|\eta| \text {, for competitive } \\
& \text { to monopolistic. }
\end{aligned}
$$

\section{Efficiency Gains for Merging Firms Only}

The proofs so far assume implicitly that all firms in the market achieve efficiency gains and all benefit from market power effects. If we assumed instead that a merger increased market power for the entire industry but lowered costs only for the merging firms, the required reductions in marginal cost would be greater. Large cost reductions for some but not all firms in an industry would be unstable - the other firms would need to obtain major efficiency gains or risk going out of business. For this reason, we cannot generally derive a numerical value for the marginal cost savings necessary to keep price from rising.

\section{E. Critical Elasticities of Demand}

Suppose (following note 89) that we have a Cournot market with constant elasticity of demand. For what value of $|\eta|$ would price increase by exactly $x \%$ if the firms colluded? This value of $|\eta|$ is the "critical elasticity of demand."

Equations (2') and ( $\left.3^{\prime}\right)$ give the equilibrium conditions for Cournot and monopolistic pricing, respectively. By assumption, in moving from $\left(2^{\prime}\right)$ to $\left(3^{\prime}\right)$, price has increased by $x \%$. Thus, 
(17) $\quad \mathrm{P}_{3}=\mathrm{P}_{2}(1+x / 100)$.

To find the value $\left|\eta^{*}\right|$ that enables price to rise by exactly $x \%$, we substitute equations $\left(2^{\prime}\right)$ and $\left(3^{\prime}\right)$ into (17) to obtain:

$$
\begin{aligned}
\mathrm{R} & =\mathrm{MC}_{3} /\left(1-1 /\left|\eta^{*}\right|\right) \\
& =\left[\mathrm{MC}_{2} /\left(1-\mathrm{hhi} /\left|\eta^{*}\right|\right)\right][1+x / 100]
\end{aligned}
$$

(19) $\left|\eta^{*}\right|=(100+x-100 h h i) / x$.

The table below shows the values of the critical elasticities that correspond to various premerger HHIs for price increases of $5 \%$ and $10 \%$, assuming constant elasticity of demand.

$\underline{\mathrm{HHI}}$

0

2500

5000

7500 $\underline{x=10 \%}$

11

8.5

6

3.5 $x=5 \%$

21

16

11

6 


\section{California Law Review}

\begin{tabular}{llll}
\hline \hline Vol. 77 & JULY 1989 & No. 4 \\
\hline
\end{tabular}

Copyright (ㄷ 1989 by California Law Review, Inc.

\section{BOARD OF EDITORS}

1988-89

Editor-in-Chief

JEFF BLEICH

Managing Editor MARK ABBOTT

Senior Articles Editor

LAURA FASHING

Articles Editors

SUNHEE JUHON

RANDALL R. LEE

JON TIGAR

Book Review Editor

KENNETH JOHN SHAFFER

Paul Ades

LANCE W. BRIDGES

MARCELyN R. COX

Gerald Carroll

Charles Q. Clay, III

TIM DEWITT

Rosemary A. Filou

JAMI FLOYD

ANTHONY PEARSALL
Senior Executive
Editor
ELLEN E. KAULBACH

Executive Editors

Mike Boro

Stuart N. SENATOR

Michael TUBACH

Technical Editor

Howard Yellen

Associate Editors

SCOTT GARDNER

JONATHAN GRAUBART

GARY S. HARRISON

Martina A. Hone

CYNTHIA K.Y. LEE

JEFFREY J. LEWIS

ANDREW MCCARTHY

MARK MERVA

Mcmbers
Senior Note \& Comnient Editor

KAREN KENNARD

Note \& Comment Editors ADAM C. BELSKY

ALISON KEEL

Paul Startz

Research \& Topics Editor RALPH KOKKA

BRAD MIDDleton

PHILIP MONRAD

JANICE NADLER

HELEN NORTON

SUE OKUDA

ANTHONY ORZA

Tamara Powell

Marco Quazzo

JiLL RoBINSON 


\section{California Law Review}

\begin{tabular}{lll}
\hline Vol. 77 & JULY 1989 & No. 4 \\
\hline \hline
\end{tabular}

Copyright (C) 1989 by California Law Review, Inc.

\section{BOARD OF EDITORS}

1989-90

Editor-in-Chief
JOHN TINKHAM

Managing Editor

JoHN F. CHASE

Senior Articles Editor

STEVE FRIEDLANDER

Articles Editors

JULIET BROWNE

LINDA FOY

Patricia L. Godsey

Michael Miller

Eric M. Brooks

David B. FELDMAN

ERIC GraNT

STEVEN HARDY

JON HINCK

DAVID P. HUBBARD

LIBBY JACOBS

MiRanda Kane

NANCY KIM
Sentor Executive Editor

JENNIFER UPHAM

Executive Editors

RICHARD E. LEAHY

HELEN SHIN

Laurine Tuleja

Research \& Topics Editor

KIM THOMPSON

Associate Editors

MARgaret LIN

David MCGowaN

Clare Maier

MiChaEl MORRISSEY

SCOTT G. PARKER

MARIA RABASSA

ROBERT RENNER

STEVEN RINKLE

ROBIN ROGERS

Office Manager

Mary P. Nelson
Senior Note \& Comment Editor

RUSS ELMER

Note \& Comment Editors

CHRISTOPHER CONNER

MAReta C. Hamre

NAOMI ROHT-ARRIAZA
Catherine Salton

TAMARA SEYler-JAMES

ROBERT SILTANEN

JOHN SITHER

MELISSA THOMAS

MORGAN SMOCK

MARIA ISABEL TAN

JANA WINOGRADE 
